\title{
A review of malaria vaccine clinical projects based on the WHO rainbow table
}

Lauren Schwartz ${ }^{1,2}$, Graham V Brown ${ }^{3}$, Blaise Genton ${ }^{4,5}$ and Vasee S Moorthy ${ }^{1,6^{*}}$

\begin{abstract}
Development and Phase 3 testing of the most advanced malaria vaccine, RTS,S/AS01, indicates that malaria vaccine R\&D is moving into a new phase. Field trials of several research malaria vaccines have also confirmed that it is possible to impact the host-parasite relationship through vaccine-induced immune responses to multiple antigenic targets using different platforms. Other approaches have been appropriately tested but turned out to be disappointing after clinical evaluation.

As the malaria community considers the potential role of a first-generation malaria vaccine in malaria control efforts, it is an apposite time to carefully document terminated and ongoing malaria vaccine research projects so that lessons learned can be applied to increase the chances of success for second-generation malaria vaccines over the next 10 years.

The most comprehensive resource of malaria vaccine projects is a spreadsheet compiled by WHO thanks to the input from funding agencies, sponsors and investigators worldwide. This spreadsheet, available from WHO's website, is known as "the rainbow table". By summarizing the published and some unpublished information available for each project on the rainbow table, the most comprehensive review of malaria vaccine projects to be published in the last several years is provided below.
\end{abstract}

\section{Background}

Few recent malaria vaccine review articles have attempted a comprehensive outline of all clinical trials that have occurred globally. The field has grown to such an extent that it is now very difficult to summarize all projects in a single review. The increase in funding over the last 10 years has allowed over 40 vaccine projects to reach the clinical trial stage. This manuscript is a comprehensive review of malaria vaccine clinical projects written in recent years, though even here it is possible that not every project has been included.

WHO compiles the "rainbow table" spreadsheet, a comprehensive publicly available collation of global malaria vaccine project activity with input from funders, sponsors and investigators [1]. For this review, published papers related to each project from the rainbow table were obtained, and clinical trial registry information and

\footnotetext{
* Correspondence: moorthyv@who.int

'Initiative for Vaccine Research, Department of Immunization, Vaccines \& Biologicals, World Health Organization, Avenue Appia 20, 1211-CH 27 ,

Geneva, Switzerland

Full list of author information is available at the end of the article
}

conference abstracts were read, where papers are not yet published.

As this review is based on projects which have reached the clinic, it is best seen as a documentation and discussion of projects which have reached that stage. This review does not present the status of current pre-clinical malaria vaccine development, other than some discussion on links between pre-clinical and clinical results for the projects outlined below.

\section{Status of malaria control}

Between 2000 and 2009 there have been major gains in malaria control in many malaria-endemic countries, including many in Africa [2]. Total estimated numbers of deaths related to malaria have dropped from about 1 million in 2000 to about 780,000 in 2009. The numbers of clinical cases are estimated at 225 million globally by WHO [3]. These gains are associated with scaling-up of existing WHO recommended malaria control measures, including long-lasting insecticidal nets (LLIN), indoor residual spraying programmes (IRS) and access to artemisinin combination therapy(ACT)[3]. There has also been a shift towards use of rapid diagnostic tests and

\section{Biomed Central}


away from presumptive treatment of malaria. Success of malaria control is vulnerable to the emergence of resistance to artemisinins and insecticides and depends on the vital imperative for sustained malaria control funding. Of the five species of Plasmodium that are known to cause disease in humans, two have received attention for vaccine development. Over $90 \%$ of malaria-related deaths are caused by Plasmodium falciparum, and there is a similar dominance for $P$. falciparum projects in the malaria vaccine landscape. A single Plasmodium vivax project is currently in the clinic; this is listed at the end of the review.

\section{Rationale and goals for malaria vaccine development}

Many lines of evidence indicate that humans can be vaccinated against malaria. Individuals born in endemic areas who survive the first years of exposure continue to develop parasitaemia on natural exposure, but become resistant first to severe, life-threatening malaria and then to clinical disease. Frequent re-exposure is required to maintain this condition of immunity with infection (concomitant immunity). Transfer of gamma-globulin fractions from semi-immune to naïve humans mitigates malaria disease $[4,5]$, demonstrating that clinical protection from malaria is possible, and that immunoglobulin targeting malaria antigens can play a critical role. Inoculation of humans with irradiated sporozoites by mosquito bite can prevent the emergence of blood-stage infection after subsequent experimental challenge [6,7], demonstrating the possibility of inducing high level protection against infection under experimental conditions. In endemic areas with natural exposure, sterile immunity rarely if ever develops. Perhaps most importantly and significantly, the candidate vaccine RTS,S/AS can induce clinical efficacy in the $25-60 \%$ range in different malaria endemic settings. Thus, the question of feasibility of malaria vaccination has progressed to an assessment of the public health role of RTS,S vaccination and the possibility of developing even more efficacious second-generation vaccines.

The Malaria Vaccine Technology Roadmap launched in 2006 expressed intermediate and aspirational community goals for vaccine benefits. First, a vaccine with $50 \%$ efficacy against severe disease and malaria-related mortality protecting for more than 12 months, and secondly a longer-lasting vaccine with $80 \%$ efficacy against clinical malaria [8]. The primary refinement introduced by the malaria eradication $R \& D$ agenda setting process during 2009-2010 is the confirmation that for elimination and global eradication, impact on transmission rather than morbidity is the paramount efficacy outcome. There is general agreement that malaria eradication is not possible with the currently available tools. Development of a highly efficacious malaria vaccine which dramatically reduces transmission would be a transformative tool that could enable future eradication.

\section{Overview of current status of malaria vaccine clinical development}

Funding has increased substantially over the last 10 years with contributions from agencies such as the Bill and Melinda Gates Foundation (particularly through PATH Malaria Vaccine Initiative), the US National Institute for Allergy and Infectious Disease, European Union DG RTD, United States Agency for International Development, Wellcome Trust, Medical Research Council UK, the European Vaccine Initiative (formerly EMVI), European and Developing Countries Clinical Trials Partnership and WHO [9]. There was a lag of several years before the funding led to a large increase in the numbers of clinical trials.

Pre-erythrocytic malaria vaccines designed to produce sterile protection can be terminated at the challenge trial stage if no efficacy is demonstrated, whereas blood stage vaccines generally progress to field evaluation for proof of concept of clinical effect; thus the timelines to reach proof of concept for blood-stage vaccines have been much longer than for pre-erythrocytic vaccines. This may explain why there are more potential bloodstage vaccines than other life-cycle stages in clinical evaluation, while many pre-erythrocytic concepts have been tested to failure and terminated, and others are in the pipeline. Substantial investment in field trial sites for blood-stage (and pre-erythrocytic) vaccine evaluation took many years, but is now bearing fruit. Because of the high cost of large-scale clinical trials, major efforts continue to find surrogate predictors of efficacy, such as reduction in incidence of infection, that could be used to prioritize candidates for the long and expensive clinical field trials. Others are reassessing the evaluation paradigm for blood-stage vaccines and considering use of the challenge trial model, together with functional assays as markers for the down-selection step. Sexual stage and mosquito antigen vaccines are receiving renewed attention but are still grossly under-represented in clinical project portfolios.

Plasmodium falciparum is a highly immuno-evasive, multi-stage protozoal parasite with several antigenically distinct mosquito vector and human stages. Molecular understanding of naturally acquired immunity remains in its early stages and there are few well characterized molecular targets that could be selected with confidence by vaccine developers as being the basis for subunitbased protection. Thus it is no surprise that many of the necessarily empiric projects outlined below have not yielded clinical efficacy [10]. Despite the success of the $P$. falciparum, A. gambiae and human genome projects, there has been little translation of antigenic targets from 
post-genomic antigen discovery to clinical evaluation, partly because of the problems of selecting appropriate targets, and the lack of robust and reliable predictive animal models. What is perhaps more surprising, given the daunting nature of the task, is that malaria vaccine developers have produced startling progress in several areas.

The first human anti-parasite vaccine will be considered for licensure by regulators in the next few years, as RTS,S/AS01E progresses through clinical evaluation in a pivotal Phase 3 trial. This product was developed through a partnership between GSK and PATH Malaria Vaccine Initiative, with funds from the Gates Foundation to MVI. Multiple other projects have yielded a degree of efficacy, notably prime-boost pre-erythrocytic projects, and very significant expertise and infrastructure has been developed in African field trial sites. The recent reductions in malaria transmission in Africa, if sustained, will render field efficacy trials more difficult in many current research settings. For some funders, this drop in transmission together with the partial success of RTS,S has shifted emphasis away from bloodstage vaccines towards pre-erythrocytic and sexual stage/mosquito (SSM) antigen vaccine development, emphasising the role they could play in further reduction of transmission. Clinical evaluation of SSM vaccines will however be challenging because these vaccines confer efficacy to humans only at the population level and thus traditional individually randomized trial designs will not apply without major modification [11,12]. An additional problem is the lack of knowledge of the relationship between the effect of a vaccine at an individual level, such as rendering an individual 80\% less infectious to mosquitoes, and the effect on transmission. For example, the effect on transmission of a vaccine that makes $\mathrm{x} \%$ of people $\mathrm{y} \%$ less infectious is not known, although some insights can be gained from modelling.

Success with the novel adjuvants used with RTS,S is now coupled with an interest in various conjugation or particulate technologies in attempts to overcome the poor immunogenicity of soluble monomeric recombinant malaria proteins [13]. Identification of scalable manufacturing processes remains challenging and laborious for many $P$. falciparum antigens that have complex multiply disulphide bonded structures and conformationally dependent induction of protective IgG. The success of malaria control also raises the bar for the expected performance of a malaria vaccine. Finally an increased emphasis on $P$. vivax R\&D has been announced by some funders, and this has already led to evaluation of one new $P$. vivax candidate in Phase 1 [14].

All but one of the projects detailed below is based on a $P$. falciparum antigen. It is likely there will be more emphasis on $P$. vivax in future as this species becomes relatively more important from the public health perspective. As many of the projects involve multiple partners and funders we have chosen not to provide details of the vaccine development partnerships here, to avoid providing incomplete information. These can easily be found through the references, the clinical trial registry sites and on the WHO malaria vaccine rainbow table [1].

The classification of projects below is by species, with $P$. falciparum projects first, and by life-cycle stage. For each life-cycle stage we report currently active projects first, followed by discontinued/inactive projects. It is important to note that many of the discontinued/inactive projects have contributed greatly to understandings of vaccine science [10], and that some will return to the clinic either in new iterations or without substantial changes if further funding is obtained. There is a separate section for combination vaccines including multiple life-cycle stages. Combination or polyvalent/multi-epitope constructs focusing on one life-cycle stage are highlighted as such within the text.

\section{Plasmodium falciparum pre-erythrocytic projects}

There is no consensus that pre-erythrocytic immune responses gained through natural exposure, whether antibody or cell-mediated immunity (CMI), contribute substantially to naturally acquired immunity [15], but the irradiated sporozoite model proves that humans can be protected by immune responses to sporozoite and liver-stage parasites. In this sense, sterile immunity conferred by pre-erythrocytic subunit vaccines or attenuated whole organisms would not be mimicking naturally acquired immunity, yet this induced "non-natural" immunity could be more effective than is seen in nature, whether it supplements or replaces that usually seen in an endemic area. Candidate vaccine antigens from the pre-erythrocytic stages may be the targets of antibodies that prevent sporozoite invasion of hepatocytes or the targets of cellular immune responses that kill infected hepatocytes. A completely effective pre-erythrocytic vaccine would inactivate the parasite before it left the liver, leading to sterile immunity and prevention of disease. This goal may or may not be achievable with the vaccines that are currently being evaluated, but a partially effective vaccine could decrease the incidence of new infections, and decrease the number of merozoites exiting the liver, by decreasing the number of sporozoites entering the liver or killing parasites within hepatocytes, leading to clinical benefits analogous to the direct effects of insecticide treated bed nets. Partially effective pre-erythrocytic vaccines could lead to reductions in both the size and frequency of blood-stage inocula, which could result in reductions in mild disease, severe disease and mortality. A reduced size of inoculum that lengthens the 
gap between infection and patency may allow time for boosting other immune responses that contribute to clinical immunity. Reduction in multiplicity of infection would be another predicted and potentially important effect of such partially effective vaccines.

\section{CS protein}

The Plasmodium circumsporozoite protein (CS) is expressed during the sporozoite and early liver stages of parasitic infection [16]. This protein is involved in the adhesion of the sporozoite to the hepatocyte and invasion of the hepatocyte. Anti-CS antibodies have been shown to inhibit parasite invasion and are also associated with a reduced risk of clinical malaria $[17,18]$ in some studies, though the relative importance of anti-CS responses in naturally acquired immunity remains controversial. Antibodies raised through immunization with only the conserved Asparagine-Alanine-Asparagine-Proline (NANP) amino acid repeat sequence, the immunodominant B-cell epitope from P. falciparum CS, are capable of blocking sporozoite invasion of hepatocytes [19]. The demonstrated protective role of vaccineinduced anti-CS responses and the fact that CS is the predominant surface antigen of sporozoites [19], have made CS the most popular antigen for use in pre-erythrocytic vaccine candidates. In this regard it is set apart from other candidate vaccine antigens, as the lead antigen. Evidence for antigen specific vaccine-induced efficacy against morbidity is far stronger for CS than any other antigen.

\section{RTS,S/ASO1E}

Clinical development of RTS,S/AS01E has been reviewed extensively [20-22]. This is by far the most advanced candidate malaria vaccine, is the only one in Phase 3 evaluation, and is at least 5-10 years ahead of all other projects. RTS,S/AS01E has demonstrated 51\% efficacy (95\%CI 29-66) in reducing the rate of all episodes of clinical malaria over fifteen months of follow-up in a Phase 2 trial in children aged 5-17 months resident in Kilifi, Kenya [23]. Immunologic analyses indicate that high titre anti-CS IgG are most strongly associated with RTS,S-mediated protection, with an important additive component from CS-specific Th1 cells. One recent study highlighted a correlation between CS-specific $\mathrm{TNF} \alpha(+) \mathrm{CD} 4(+) \mathrm{T}$ cells and reduced morbidity, which requires confirmation in other studies [24]. The ongoing Pivotal Phase 3 trial started in May 2009 and has enrolled 15,460 children over 6,000 of whom are in the 6-14 week EPI co-administration age group. The full trial results are expected in 2014 and will include the following information: safety and reactogenicity of a vaccine containing a novel adjuvant, co-administration data with pentavalent $\mathrm{DTwP} / \mathrm{HepB} / \mathrm{Hib}$ and $\mathrm{OPV}$, efficacy in multiple transmission settings, efficacy data over 30 months of follow-up, an 18 month booster dose and efficacy against severe, life-threatening malaria. The first of 3 sets of results from the Phase 3 trial was published on 18 Oct 2011 and was in line with expectations from the Phase 2 trials $[25,26]$. The trial, conducted at 11 trial sites in seven countries across sub-Saharan Africa, reported that RTS,S reduced the incidence of all episodes of clinical malaria by $55 \%$ (95\%CI 51-59) when evaluated over 12 months following the third dose. This analysis was performed on data from the first 6,000 children aged 5 to 17 months. A primary analysis for severe malaria efficacy was planned when 250 cases accrued in both the 5-17 month and 6-14 week age groups of the trial. This analysis reported an efficacy of 35\% (95\% CI 16-49) with variable follow-up from zero to 22 months after the third dose. There are many lessons to be learned from the RTS,S trials including the major contribution of sporozoite challenge trials, the importance of adjuvant, dose and schedule optimization, and the need to use particulate structures to enhance immunogenicity.

There is a standing WHO advisory group, known as the Joint Technical Expert Group, which will review data as they become available from the Phase 3 trial. Policy recommendation timings are data-driven. Depending on the full trial results expected in 2014, WHO recommendation for use may occur in 2015.

\section{Adenovirus (Ad35) vectored CS}

RTS,S/AS01E induced very potent anti-CS Ig responses, modest CD4+ $\gamma$-interferon $\mathrm{T}$ cell responses and low or absent CD8 responses. The approach considered most likely to improve upon CS-mediated protection would be to employ a prime-boost combination of RTS,S/AS01 with a CD8-inducing CS vaccine. The non-replicating adenovirus 35 vector encodes the CS protein. In preclinical development the vaccine induced strong IFN- $\gamma$ responses in mice including $\mathrm{CD} 8+$ responses, thought to be important for protective immunity in humans $[27,28]$. Phase 1 human studies examining safety and immunogenicity have occurred at Stanford and Vanderbilt Universities [29] with a Phase 1b study in Burkina Faso now completed [30]. The potential interference of antibodies induced by previous natural exposure to Ad 5 is not known, but one attraction for adenovirus 35 is the much lower seroprevalence of antibodies to this virus than adenovirus 5 [31]. The HIV STEP trial results [32] are thought by some to represent a roadblock to the future of adenovirus 5 as a vector for prophylactic vaccine.

\section{Ad35 vectored CS in prime-boost with RTS,S/ASO1E}

Crucell announced in 2009 that they have agreed to work with GSK to evaluate adenovirus 35 CS/RTS,S prime-boost combinations, hopefully reproducing the promising non-human primate results seen with this approach [33]. Regimens based on RTS,S/AS01, but 
including rational prime-boost additions or additional antigens in combination, are the most likely near-term possibilities for improving efficacy induced by RTS,S/ AS01 alone. The Phase 1/2a sporozoite challenge study began in August 2011 comparing one dose of Ad35 CS followed by two doses of RTS,S/AS01 with 3 doses of RTS,S/AS01 alone [34].

\section{Multiple epitope constructs}

Some vaccine strategies use components of multiple pre-erythrocytic antigens in one vaccine to elicit a broad immune response intended to prevent blood-stage infection. This approach is intermediate between traditional single antigen constructs and combinations of whole antigens. One example is the ME-TRAP construct, a pre-erythrocytic fusion antigen consisting of $17 \mathrm{~B}$ cell, CD4+ and CD8+ T cell epitopes from six P. falciparum antigens fused to the T9/96 allele of TRAP (thrombospondin-related adhesion protein) pre-erythrocytic antigen. It includes a single Plasmodium berghei CD8+ T cell epitope $(\mathrm{Pb} 9)$ for potency studies in mice. The vaccine construct is based on the attractive concept of IFN$\gamma$ mediated elimination of infected hepatocytes [35,36]. TRAP is another protein expressed both on the surface of sporozoites [37] and within infected hepatocytes [38].

\section{AdCh63/MVA ME-TRAP}

During preclinical development of this vaccine, a primeboost sequence of simian adenovirus (AdCh63) encoding for ME-TRAP boosted with modified vaccinia virus Ankara (MVA) encoding the same construct elicited exceptionally strong and long-lasting CD8+ T cell responses [36,39]. Initial studies had used human adenoviruses, but previous exposure to the vector could produce neutralizing antibodies that would interfere with immunogenicity. This problem is overcome through use of simian adenovectors to which humans do not have cross-reactive antibodies. In the UK a Phase 1 study and a Phase 2 sporozoite challenge study should be completed during 2011 [40,41]. The first adult Phase1 Kenyan study had started by November 2010 and a Phase $1 \mathrm{~b}$ field trial in the Gambia has also occurred [1]. Prime-boost approaches including adenoviruses appear particularly promising for achievement of the long desired outcome of strong induction of CD8 T cell responses in humans; the strain of adenovirus used may be vital to the immunogenicity and efficacy afforded, both in malaria-naïve individuals and in malaria-endemic settings.

\section{Polyepitope DNA EP1300}

This pre-erythrocytic DNA vaccine includes multiple epitopes with linker sequences from four pre-erythrocytic antigens, CS, SSP2/TRAP, Liver-stage antigen 1 (LSA-1) and Exported protein 1 (Exp-1) and is administered via electroporation. The strategy is being assessed in Phase 1a studies in naive volunteers in the US which started during 2010 [42]. Few further details are available. The immunogenicity of DNA vaccines in animal models has generally not been reproduced in humans. Augmentation has previously been attempted with various intradermal, subcutaneous and intramuscular delivery devices [43]. Electroporation has augmented immune responses impressively in some animal models $[44,45]$ and in a Phase 1 clinical trial of an HIV vaccine construct [46]. It remains to be seen whether tolerability will be acceptable and immunogenicity sufficient for prophylactic paediatric vaccination in humans. This project also touches on the important question of how to best ensure immunogenicity of multiple epitopes or antigens in DNA-based approaches.

\section{Whole organism approaches PfSPZ: metabolically active, non-replicating malaria sporozoite vaccine}

Using the knowledge that volunteers can be protected from sporozoite challenge by immunization via bites from $>1,000$ irradiated P. falciparum-infected mosquitoes, a biotech company has developed an approach using injection of metabolically active, non-replicating whole $P$. falciparum sporozoites thawed from long-term storage in liquid nitrogen. The vaccine should confer sterilizing immunity in principle, but challenges arise from manufacturing and scaling up of the product, dosage and administration methods, and the logistics of delivering a vaccine that is cryopreserved in liquid nitrogen [47-49]. In initial Phase 1/2a studies to examine the safety and immunogenicity of different dosages and i.d. and s.c. routes of administration in malaria naïve volunteers [50], two out of 44 subjects challenged were completely protected, but refinements to the dose, route or schedule or improvements in adjuvants are required for a vaccine likely to have significant impact on morbidity. With such a novel vaccine technology, it is likely that several further Phase 1 trials will be necessary to identify a regimen that can replicate the results previously seen when irradiated sporozoites were delivered by mosquito bite. A follow-on Phase 1/2a of i.v. administration is underway [51].

\section{Genetically attenuated sporozoites}

Another whole organism approach is inoculation of genetically attenuated parasites. A multi-institutional partnership is developing and testing genetically attenuated sporozoites as whole organism pre-erythrocytic immunogens [52,53]. A Phase 1 study has occurred; no report had been made at the time of writing.

\section{Discontinued/inactive pre-erythrocytic projects FP9 CS/MVA CS}

This strategy assessed whether priming with an attenuated fowlpox strain (FP9) expressing the pre-erythrocytic 
CS protein and boosting with MVA also coding for the CS protein would elicit strong cellular responses. A Phase $1 / 2$ a study in malaria naïve subjects in the UK found that while the vaccine regimen was safe, the $T$ cell response was modest and MVA did not boost this $\mathrm{T}$ cell response convincingly. When challenged with sporozoites, there was no protection of study subjects and no partial protection, defined by a delay in time to parasitaemia [54]. Conversely, in a Phase 1b study in Gambian adults, IFN- $\gamma$ producing CD4+ and CD8+ cells were substantially elevated after boosting with MVA with the most likely explanation being priming of the response by natural infection [55]. Interestingly this result was predicted by earlier pre-clinical research on natural priming performed by a group at New York University [56].

\section{DNA CS/MVA CS}

This prime-boost regimen replaced FP9 above with a plasmid DNA encoding the CS protein as a priming agent. In a Phase $1 / 2 \mathrm{a}$ study in the UK, the $\mathrm{T}$ cell response was again modest and there was no difference in time to parasitaemia between those vaccinated and the controls after sporozoite challenge [57]. Thus whether DNA/poxvirus or heterologous viral/viral prime-boost approaches are used, the ME-TRAP construct seems to be substantially more immunogenic than the CS construct. This is an important lesson for future projects; one reason for failure of a given primeboost regimen may be an insufficiently immunogenic antigen and should not necessarily be ascribed to the choice of priming and boosting platforms alone.

\section{RTS,S/ASO2 + MVA CS}

This vaccine regimen was assessed in order to determine if boosting RTS,S/AS02 with MVA encoding the $P$. falciparum CS protein would elicit equivalent antibody titres but greater CMI response than RTS,S/AS02 alone. A Phase $1 / 2 \mathrm{a}$ study in malaria naïve adults in the UK found the prime-boost combination to be safe, but elicited little or no incremental benefit for this regimen compared with RTS,S alone. After sporozoite challenge, vaccine efficacy for complete protection was $2 / 6$ volunteers, the same order of magnitude as protection seen with RTS,S/AS02 alone in previous studies. As with RTS,S/AS02 alone, some volunteers showed a delay in parasitaemia. Disappointingly, MVA-CS did not augment the CS-specific CMI response to RTS,S/AS02 [58]. The objective of this study remains highly relevant as the community searches for alternative viral vectors which could augment the CD8 CMI response to RTS,S.

\section{CS DNA immunization}

In this strategy, the gene for full length CS protein was inserted into naked plasmid DNA. Multiple Phase 1a studies assessed the safety and immunogenicity of this vaccine, also named VCL-2510, using intramuscular, intradermal and needle-free delivery to induce humoral and cellular responses. While all routes of delivery were safe and elicited some CD8+ T cell responses, no antiCS antibodies were detected [59-61]. These early studies demonstrated that DNA vaccines alone were substantially less immunogenic in humans than had been observed in small animal models.

\section{MuStDO5 (Multi-Stage DNA vaccine Operation, 5 antigens)}

This is a combination of DNA plasmids that encode CS, SSP2/TRAP, Exp1, LSA1 and LSA3 adjuvanted with GM-CSF (Granulocyte Macrophage Colony Stimulating Factor). There was no efficacy detected in the challenge study [62] and the investigators have now moved away from DNA plasmid immunization alone.

\section{DNA CS/RTS,S/ASO2}

The DNA vaccine VCL-2510 containing the full length $\mathrm{CS}$ gene had been shown to elicit some CD8+ T cell responses and RTS,S/AS02A had elicited CD4+ T cell and anti-CS IgG responses. Vaccination with VCL-2510 followed by boosting with RTS,S/AS02 12-14 months later was safe and immunogenic. The anti-CS antibody and CD4+ response among those boosted was not significantly different from those vaccinated with RTS,S alone, but the DNA/protein prime-boost regimen induced memory CD8 $+\mathrm{T}$ cell responses not seen among those vaccinated with only RTS,S [63,64]. However CD8+ T cell $\gamma$-interferon responses were not induced as measured by ELISPOT assays conducted on freshly isolated cells.

\section{RTS,S/ASO2 and TRAP}

There is currently no published literature available on this project, but a Phase 2 a challenge trial with this vaccine has taken place [1]. It is very important to understand the study design and the outcomes of the project, because combination of CS and TRAP recombinant protein vaccines is a highly logical approach to improving upon RTS,S-mediated efficacy to date. It will be important to determine whether this approach has been adequately tested to failure, or whether further trials are justified with improved TRAP-based recombinant protein constructs.

\section{HepB Core-Ag CS VLP}

Several clinical studies have assessed this vaccine, also called ICC-1132 or Malarivax, a virus like particle with hepatitis $\mathrm{B}$ core antigen genetically engineered to include one B cell epitope and $2 \mathrm{CD} 4+\mathrm{T}$ cell epitopes of the CS protein and expressed in E. coli. Phase 1 studies of the vaccine adjuvanted in alhydrogel showed acceptable safety with anti-ICC-1132 antibody and IFN$\gamma$ induction, but limited malaria specific anti-CS antibodies [65]. Reactivity in functional assays was present in a proportion of vaccinees [66]. When the vaccine was adjuvanted with Montanide ISA 720 and given as a single dose, volunteers seroconverted for IgG to CS but at 
lower titres than have occurred after 2-3 doses of RTS,S adjuvanted with AS01, 02 or 03 [67]. Although 2 or 3 dose regimens may have been more immunogenic, a single dose ISA 720 regimen was chosen for evaluation in a challenge trial because sterile abscess formation had been seen in non-human primates after 2 doses of ICC1132 in ISA 720. The challenge trial showed no efficacy against sporozoite challenge [68]. Not long after this study ICC-1132 development was discontinued.

\section{CS long synthetic peptide}

PfCS102 is a chemically synthesized segment of the $P$. falciparum CS protein containing the C-terminal region with amino acids 282-383. Several Phase 1 studies examined this vaccine construct at varying dosages and combined with different adjuvants. The first Phase 1a study examined PfCS102 adjuvanted with Montanide ISA 720 and alum. Overall, both vaccines were safe and elicited lymphocyte proliferation in all subjects. The ISA 720 adjuvanted vaccine elicited higher antibody levels and enhanced functional activity. Cellular responses were short lived [69]. A second Phase 1a studied examined the vaccine adjuvanted with ISA 720 and GSK's AS02A. In this study AS02A induced stronger humoral and cellular responses [70]. During the $1 / 2 \mathrm{a}$ challenge study, conducted with Montanide ISA 720 alone, all volunteers including controls and vaccinees developed malaria with no difference in time to parasitaemia [71]. There is much debate about the importance of using full length CS, and several groups are now exploring pre-clinical development of full length CS constructs.

\section{FP9/MVA \& DNA/MVA ME-TRAP}

In order to identify the safest and most immunogenic prime-boost regimen to elicit cellular immunity to the liver stage antigen ME-TRAP, multiple non-replicating viral vectors were compared in Phase $1 / 2$ a clinical studies in the UK and several field studies in malaria endemic regions [72]. The current clinical programme is focusing on AdCh63 priming and MVA boosting, a regimen confirmed to be highly immunogenic. Prior to this selection, attenuated fowlpox (FP9) or plasmid DNA for priming, followed by MVA boosting had been assessed. Both prime-boost regimens were safe and elicited strong cell-mediated IFN- $\gamma$ responses, with DNA/MVA METRAP eliciting a stronger response in CD4+ T cells and FP9/MVA ME-TRAP stimulating more CD8+ T cells $[73,74]$, though much weaker CD8 induction than seen with AdCh63/MVA. After a challenge study in malaria naïve adults showed complete protection in some volunteers, Phase $1 \mathrm{~b}$ studies in Kenyan adults and children assessed the safety and immunogenicity of FP9/MVA ME-TRAP $[75,76]$. These trials also demonstrated strong IFN- $\gamma$ responses via ex vivo and cultured ELISPOT [77]. A Phase 2 study in Kenyan children resulted in a lower than anticipated $\mathrm{T}$ cell response and the vaccine afforded no protection against febrile malaria [78,79]. Earlier trials examining the DNA/MVA ME-TRAP prime-boost vaccination schedule in adults from the UK demonstrated an increase in CD4+ and CD8+ IFN- $\gamma$ producing cells and a delay in time to parasitaemia compared with homologous vaccination [80]. While field trials in the Gambia of the same vaccine regimen confirmed good $\mathrm{T}$ cell immunogenicity, the efficacy in terms of time to first infection was only 10.3\% (95\%CI -22-34) [81]. These trials also confirmed that priming by naturally acquired infection could be boosted by recombinant poxviruses [82].

\section{FP9/MVA polyprotein}

This prime-boost strategy combined the non-replicating viral vectors FP9 and MVA. The very long (3,240 amino acid) polyprotein encoded by the vectors consisted of 6 antigens; liver stage antigen-3 (LSA3), sporozoite threonine and asparagine rich protein (STARP), Exp1, Pfs16, TRAP, and LSA1. During the preclinical Phase, the vaccines elicited promising $\mathrm{T}$ cell responses to each of the six antigens in certain inbred mouse strains [83], but clinical development ceased due to low efficacy in sporozoite challenge [84]. This was disappointing, because the capacity of poxviruses to encode very large inserts, could be a way to include multiple antigens, if single antigen approaches prove inadequate. It may be that optimization of expression, for example with multiple promoters, could improve upon the results seen with this construct.

\section{FMP011/AS01B (LSA-1 E. coli-expressed evaluated with $A S 02 A$ and $A S 01 B$ adjuvants)}

LSA-1 is a pre-erythrocytic antigen expressed only in infected hepatocytes and LSA-1 antibodies have been associated with reduced risk of malaria blood-stage infection [85]. This candidate used LSA-NRC, an antigen containing $\mathrm{T}$ cell epitopes of the $\mathrm{N}$ and $\mathrm{C}$ terminal regions of LSA-1 and several central amino acid repeats. The antigen was expressed in E. coli and used with GSK adjuvants AS01B or AS02A. In a Phase $1 / 2$ a trial the vaccines showed acceptable safety among malaria naïve adults, with high titre anti-LSA-1 antibodies. Unsurprisingly for a regimen using a recombinant protein platform, CD8+ T cells were low or undetectable among both groups. Volunteers who received a high dose of either vaccine were challenged, but none were protected and there was no delay in parasitaemia [86].

\section{LSA-3}

A liver-stage antigen 3 (LSA-3) L. lactis expressed recombinant protein has been evaluated in the clinic, adjuvanted with either aluminum hydroxide or Montanide ISA 720 [87]. During a Phase $1 / 2$ a study conducted in 2008, one volunteer developed an acute coronary syndrome in temporal association with malaria sporozoite challenge. The coronary syndrome resolved [88] and has 
led to consensus in the malaria challenge community that formal algorithmic exclusion of those at high coronary risk is appropriate as a precautionary measure in all malaria challenge trials [89]. The safety, immunogenicity and efficacy results of the LSA-3 trial have not yet been published to our knowledge. Proof-of-concept testing for LSA3 remains uncompleted for the time being.

\section{Plasmodium falciparum blood stage projects}

Transfer of immunoglobulin from immune adults to children suffering acute malaria mitigates clinical disease $[4,5]$, but it is not clear whether the targets of naturally acquired protection to severe disease, uncomplicated disease and blood stage infection overlap at a molecular level. Most studies examining incident infection have used parasite detection by microscopy as the endpoint, but it is clear that subpatent infections occur not uncommonly in partially immune people. Thus some studies describing "sterile immunity" may in fact be measuring very effective blood stage immunity that is not sterilizing but maintains parasitaemia at subpatent levels. As discussed earlier, there is little consensus on the degree of contribution of the pre-erythrocytic stages to naturally acquired immunity, but what is clear is that adults with substantial anti-disease immunity become reinfected rapidly on exposure to sporozoites in endemic countries. Furthermore, historical reports of blood-stage challenges of immune adults showed attenuated infections with immunity targeting the blood stages alone [90]. Antigenic polymorphism is a major challenge for most blood stage antigenic targets.

\section{MSP-1}

Merozoite Surface Protein 1 (MSP-1) is expressed from the onset of schizogony and is involved in erythrocyte invasion by merozoites. Much is known about the structure and function of MSP1 and the possible immune effector mechanisms of MSP1-specific immunity [91]. Anti-MSP-1 antibodies have also been associated with decreased risk of clinical malaria, in an allele-specific manner [92]. The weight of evidence is that IgG induction is more important for MSP1 than cell mediated effector responses.

AdCh63/MVA MSP1

This prime-boost strategy utilizes the simian adenovirus 63 vector boosted by MVA, both expressing portions of the $P$. falciparum MSP1 protein, including the dimorphic forms (3D7 and FVO) of the 33kd C-terminal segment as well as MSP1(19) and parts of the N-terminus. Because MSP1 is a very large protein, all clinical projects to date have attempted to identify critical segments of the whole protein for inclusion in the vaccine construct. A Phase 1 trial reported very high mixed CD4/CD8 $\mathrm{T}$ cell induction with some IgG induction in addition [93]. A Phase 2a study has also occurred $[94,95]$.

\section{FMP010/AS01B}

FMP010 is an E. coli expressed FVO allele of the $42 \mathrm{kD}$ C-terminus of MSP1 and is adjuvanted with the GSK product AS01B. A Phase 1 study examining safety and immunogenicity via growth inhibition assays has occurred [96]. Phase 1b studies were underway in semiimmune populations in Kenya in 2010 [1]. This project follows the previous studies of FMP001/AS02A, a vaccine based on the 3D7 allele of MSP1, and showing good immunogenicity but inadequate clinical efficacy in a Phase $2 b$ trial [97], possibly because multiple vaccine alleles would be necessary to generate a sufficiently broad strain-transcending immune response.

MSP-3

Merozoite Surface Protein 3 (MSP-3) is unique in that its anti-parasitic activity was discovered through the exploration of the phenomenon that passive transfer of IgG to naïve volunteers mitigated disease and was associated with reduced disease via antibody dependent cell mediated inhibition (ADCI). Search for the targets of ADCI identified the highly conserved MSP3 antigen and the resulting cytophilic IgG1 and IgG3 anti-MSP3 antibodies as sources of parasitic growth inhibition [98]. A systematic review of immuno-epidemiological studies reported that MSP3 was the blood-stage antigen with the most consistent associations between antibody responses and reduced risk of clinical malaria, in multiple settings [92]. A Phase 1a study in healthy Swiss volunteers demonstrated that the long synthetic peptide MSP3 vaccine elicited a strong humoral response with low reactogenicity when used with aluminum hydroxide adjuvant [99]. Conversely, a Phase $1 \mathrm{~b}$ trial of semiimmune adults in Burkina Faso resulted in little humoral and modest cell-mediated responses to the vaccine, most likely due to previous exposure and elevated baseline anti-MSP3 antibodies [100,101]. Two Phase 1b trials at sites in Tanzania and Burkina Faso in children aged 12-24 months reported tolerable reactogenicity and good IgG1 and IgG3 cytophilic humoral responses $[102,103]$. Over $80 \%$ of children in both dose groups had a greater than 8-fold increase in IgG subclass titre in the Tanzanian study. Further Phase 1-2 studies in Mali and Burkina Faso have commenced and should be completed during 2011. The reporting of a paediatric Phase 2b study in Mali is awaited [104]. An exploratory analysis of the Phase $1 \mathrm{~b}$ trial from Burkina Faso of MSP-3 long synthetic peptide adsorbed on aluminium hydroxide reported that rates of clinical malaria in children who received the vaccine in 2 dose groups were lower than in the control group who received hepatitis $B$ vaccine [105]. The sample size was small, and whilst 
interesting, this finding requires confirmation in a prospective Phase 2 field efficacy study.

\section{AMA-1}

Apical Membrane Antigen 1 (AMA1) is a blood-stage antigen that aids in orienting the merozoite during invasion of erythrocytes and is also expressed during the sporozoite and hepatic stages. Studies have also shown that anti-AMA1 antibodies tend to be present in those who have acquired natural immunity to malaria $[106,107]$ and repeated natural exposure often leads to high titres of IgG to AMA1. This is in contrast to CS for which even intense exposure induces quite low titres of antibody. The extreme polymorphism of this candidate vaccine antigen suggests that the human immune system exerts a strong selective pressure [108]. These both provides rationale for use of AMA1 as a vaccine in that it is subject to immune pressure, but implies that novel approaches, able to induce strain-transcending responses, will be necessary for useful efficacy.

\section{FMP2.1/ASO2A}

A Phase 1a study with malaria naïve volunteers examining the effect of vaccination with FMP2.1, in which $E$. coli expressed AMA1 (3D7 strain) is adjuvanted with the GSK product AS02A, showed acceptable safety and induction of strong humoral and cell-mediated responses [109]. In a Phase 1b study in Malian adults the vaccine was safe, induced a strong antibody response, but displayed a strongly Th-2 biased cellmediated immunogenicity $[110,111]$ in contrast to a more balanced Th1/Th2 profile in vaccinated malarianaïve adults. A Phase $1 \mathrm{~b}$ dose-escalating study of the same vaccine in Malian children induced at least 100fold rise in antibody titres compared with baseline antiAMA1 antibodies, at all three doses [112]. A Phase 2 study in 400 Malian children aged 1-6 reported no significant efficacy against the primary clinical malaria endpoint, but was consistent with allele-specific efficacy against the AMA1 allele contained in the vaccine [113].

\section{FMP2.1/ASO1B}

The FMP2.1/AS01B vaccine candidate uses the same antigen (E. coli expressed AMA1 (3D7 strain)) with the AS01B GSK adjuvant. Both adjuvants contain the same amounts of 3-D-MPL (3-deacylated-monophosphoryl lipid A) and QS-21. AS01B is liposome based while AS02A is an oil-in-water emulsion. A Phase $1 / 2$ a study in malaria naïve volunteers demonstrated high titres of anti-AMA1 antibody, inhibition of parasite growth in vitro, and strong IFN- $\gamma$ ELISPOT responses. However, after sporozoite challenge, all volunteers became parasitaemic [114]. There was an indication of reduction of the liver-to-blood inoculum for both FMP 2.1/AS02A and FMP2.1/AS01B vaccinees, but the reduction was marginal as assessed by a mathematical model of the qPCR data, with no corresponding difference in pre- patent period as measured by microscopy. There was one notable adverse event 18 days after the second FMP2.1/AS01B vaccination, a rash consistent with a cutaneous immune-mediated hypersensitivity reaction. The rash intermittently recurred at the site of the two previous vaccinations over 3 months [114].

\section{AMA-C1/Alhydrogel + CpG 7909}

The antigen for this vaccine candidate is Pichia pastoris expressed AMA1 with both FVO and 3D7 strains of AMA1. In previous studies with AMA-C1/Alhydrogel, vaccine trials resulted in low titres of anti-AMA1 antibodies and little response in the functional in vitro growth inhibitory assay. Thus the vaccine developers evaluated adjuvant combinations of Alhydrogel +/- CpG 7909, a toll-like receptor 9 agonist favouring a Th1 bias and a more potent antibody response. There has been a single case of a serious autoimmune disease known as Wegener's granulomatosis in association with a hepatitis $B$ vaccine adjuvanted with an oligonucleotide similar to CpG 7909. Therefore special attention was paid to possible autoimmune disease in these malaria studies. In a Phase 1a vaccine trial in malaria-naïve adults, addition of CpG was associated with substantially higher IgG responses and increased in vitro growth inhibition for both FVO and 3D7 strains [115]. A Phase 1b study in Mali comparing the two vaccines also showed a significantly higher geometric mean antibody titre in the CpG arm as compared to the vaccine without CpG. Difference in the growth inhibition assay activity was not significant, but investigators hypothesize this is due to interference from naturally acquired malaria specific IgG [116]. A Phase 2 study in 300 Malian children aged 2-3 evaluated AMA-C1 with alhydrogel but without CpG. There was no detectable beneficial biological impact of vaccination in terms of reduction in occurrence of parasite density above pre-defined thresholds [117]. Importantly there was an apparent reduction in haemoglobin concentration in AMA1-C1 vaccinees. As this was seen in 2 of 16 reported secondary endpoints, it should be treated with caution. However, this is a biologically plausible outcome of vaccination with an immunogen based on a blood stage antigen and further analysis is warranted. An elegant exploration of allele-specific efficacy in this Phase 2 trial has been published with no indication of an allele-specific effect [118].

\section{AdCh63 AMA1/MVA AMA1}

This vaccine strategy uses the simian adenovirus AdCh63 expressing AMA1 to prime the immune system and MVA expressing AMA1 to boost. Phase 1a studies for safety and immunogenicity as well as Phase 2a challenge trials have commenced [95,119]. There is now clinical trial data for AdCh63/MVA prime-boost with 3 different antigens. These confirm that this approach is exceptionally immunogenic for CMI, inducing average 
ELISPOT responses of greater than 1,000 spot-forming cells per million peripheral blood mononuclear cells, with $\mathrm{CD} 8$ responses being greater than $\mathrm{CD} 4$ responses. It remains to be seen whether the IgG induction will be sufficient for blood stage antigens.

\section{EBA175 RII}

The EBA175 protein is a blood stage antigen that aids binding of the merozoite to host erythrocytes. The RII region of the protein is highly conserved among the various strains of $P$. falciparum. In a recent Phase 1 study in adult malaria naïve volunteers, a recombinant protein made in $P$. pastoris, adjuvanted with aluminium-phosphate, resulted in a safe and immunogenic response at varying doses $[120,121]$. Sera from volunteers had antiEBA175 RII antibodies that demonstrated modest parasitic growth inhibition and inhibition of parasitic binding to erythrocytes in vitro. A Phase 1 study in semi-immune adult volunteers in Ghana was underway in 2010 [122].

\section{SERA5}

This blood stage antigen is expressed during the trophozoite and schizont stages. SE36 is an E. coli expressed recombinant protein corresponding to a fragment of the SERA5 antigen. Seroepidemiologic studies in the Solomon Islands found anti-SE36 antibodies to be inversely related to parasite density. In a Phase 1a vaccine trial in malaria naïve Japanese males, the vaccine candidate had acceptable safety and resulted in 100\% seroconversion [123]. A Phase $1 \mathrm{~b}$ trial in semi-immune Ugandan adults has recently been completed [124].

\section{Combinations of multiple blood stage antigens MSP1 and AMA1 combination: BSAM-2/Alhydrogel + CPG}

BSAM-2 is a combination vaccine including MSP1 and AMA1 components. It contains a mixture of recombinant proteins with equal parts $P$. pastoris expressing FVO and 3D7 strains of AMA1 and E. coli expressing the FVO and 3D7 strains of MSP1 (42). Each component is adjuvanted with alhydrogel and the solution is mixed with CPG 7909 before vaccination. A Phase 1a study in naïve adults in the US and a Phase 1b study in semi-immune Malian adult is currently taking place [125].

\section{MSP1 19 and EBA175 combination: JAIVAC}

This combination vaccine consists of MSP1(19) and EBA175, each of which is an E. coli expressed recombinant protein adjuvanted with Montanide ISA 720. A Phase 1a clinical trial has recently started in India [126]. This approach targets two antigens with distinct roles in merozoite invasion in the hope that the combination could have additive or synergistic effects over a vaccine based on one target alone [127].

MSP-3 and GLURP combination: GMZ2

The GMZ2 candidate vaccine is a L. lactis expressed recombinant fusion protein of Glutamate Rich Protein
(GLURP) and MSP3, adjuvanted with aluminum hydroxide. A Phase 1a study of the GMZ2 vaccine in malaria naïve German volunteers showed acceptable safety and reactogenicity along with induced anti-GLURP and antiMSP3 antibodies and memory B-cells [128]. A Phase 1b clinical trial in semi-immune adults from Gabon also showed acceptable safety, a boosted anti-GMZ2 cytophilic IgG response compared with elevated baseline levels, and the induction of memory B-cells [129]. A Phase 1b study in Gabonese children was recently reported [130] with both IgG and memory B cell induction confirmed for GMZ2. Phase 2b studies have been planned for Uganda, Burkina Faso, Ghana and Gabon [1].

\section{Discontinued/inactive blood stage projects RESA, MSP1, MSP2 (Combination B)}

The Combination $B$ vaccine consisted of a mixture of three antigens expressed in E. coli and adjuvanted with Montanide ISA 720. The antigens included the N-terminal blocks 1 and 2 of MSP1 (K1 allele), the full length 3D7 allele of MSP2, and a large C terminal fragment of the ring-infected erythrocyte surface antigen (RESA). In a Phase $1 / 2$ a study in malaria naïve adults all participants developed parasitaemia and did not experience any delay in growth rate as compared to controls $[131,132]$. A Phase $1 / 2$ b study in children in Papua New Guinea assessed parasite density as an efficacy endpoint. Among children who were not pre-treated with sulphadoxine/pyrimethamine there was a parasite density reduction of $62 \%$ (95\%CI 13-84), but vaccine efficacy related to prevalence of infection by microscopy, acquisition of new infections and acquisition of clinical malaria was not detected [133-136]. Molecular analyses showed that vaccinees had lower prevalence of parasites carrying a 3D7-type allele and fewer clinical episodes with this variant (corresponding to that in the vaccine). The results provided stimulus for the now discontinued MSP2 bi-allele approach.

\section{FMP1/AS02A}

Falciparum Malaria Protein-1(FMP1) contains the 42 kDa carboxyl terminus of Merozoite Surface Protein-1 (MSP1) (3D7). The antigen is expressed in $E$. coli with a histidine tag and adjuvanted with AS02A. A Phase 1a trial in malaria naïve volunteers showed the vaccine to have acceptable safety and elicited strong humoral and cellular responses, as well as functional inhibition of parasite growth [137]. Two Phase 1b studies, in Kenya and Mali, showed reasonable induction of anti-MSP1 IgG among semi-immune adults with high titres of IgG at baseline $[138,139]$. A Phase 1b study in Kenyan children confirmed acceptable safety and immunogenicity with a higher induced titre and lower baseline as expected [140]. However, the Phase $2 \mathrm{~b}$ trial in 400 Kenyan children aged 12-47 months reported vaccine 
efficacy of $5.1 \%$ (95\%CI -26-28) with no reduction in parasite density [97]. The allele-specific efficacy analyses from this trial are awaited as the absence of a strain transcending response would be one logical reason for lack of efficacy.

\section{MSP1-C1/AIOH/AIOH + CpG}

MSP1-C1 is a combination of FVO and 3D7 strains of MSP1(42) as recombinant proteins expressed in E. coli. Original formulations of the vaccine had MSP1-C1 adjuvanted with alhydrogel, but Phase 1 studies found this formulation to be only modestly immunogenic [141] with little activity in a growth-inhibition assay (GIA). In a Phase 1a study in malaria naïve subjects, addition of CpG substantially increased the humoral response to MSP1 [142,143]. We are not aware of planned further development of MSP1-C1 alone, but rather as part of BSAM-2/Alhydrogel + CpG, a MSP1/AMA1 combination [125]. A separate comparison of GIA for equivalent IgG concentrations of anti-AMA1 and anti-MSP1 antibodies confirmed that antibodies to AMA1 are far more potent for growth inhibition in vitro [144].

\section{MSP2-C1/ISA 720}

MSP2-C1/ISA 720 is a combination of 3D7 and FC27 strains of MSP2 as recombinant proteins, adjuvanted with montanide ISA 720 . While the vaccine elicited strong humoral and cellular responses in a Phase 1a study, the trial ended prematurely due to increased reactogenicity at the injection site and issues with vaccine stability [1]. The impetus for MSP2-C1 was the results from an earlier trial of Combination B [136], a vaccine which contained one allele of MSP2 and whose efficacy analyses suggested a possible MSP2-related allele-specific effect. It is therefore disappointing that the MSP2-C1 combination was not evaluated in an efficacy study. It would be beneficial to clarify whether this construct has been terminated due to funding priorities or whether it has truly been tested to failure already, funding priorities aside. Increased reactogenicity with ISA 720 is highly likely to be related to the water-in-oil formulation rather than the antigen.

\section{AMA1-C1/ISA 720}

AMA1-C1 combines the 3D7 and FVO strains of AMA1 recombinant protein, expressed in $P$. pastoris. The combination here was pre-formulated with ISA 720. A Phase 1a study of AMA1-C1/ISA 720 was terminated partway through enrolment due to a documentation problem unrelated to this particular vaccine at the pharmacy where final formulation was conducted. It is difficult to evaluate the incomplete immunogenicity data that was obtained, though the short-lived nature of the induced anti-AMA1 response was notable given the usual depotlike effect of ISA 720. Degradation in droplet size and protein integrity was also noted in long-term stability studies [145]. Both early and delayed local reactions were seen after vaccination, including an injection site nodule in one volunteer.

\section{AMA1-FVO (25-545)}

In order to compare the reactogenicity and immunogenicity of several adjuvants, this Phase 1a study examined the FVO strain of AMA1 expressed in P. pastoris and adjuvanted with either alhydrogel, Montanide ISA 720 or AS02. Generally, all three strategies were acceptably safe, but AMA1 with ISA 720 or AS02 was more reactogenic and displayed higher levels of anti-AMA1 antibodies and IFN- $\gamma$ and IL- 5 cytokines than with alhydrogel [146]. However, due to concerns about whether a single allele of AMA1 was likely to afford relevant clinical efficacy, clinical development of this AMA1 candidate has been discontinued and evolved into the AMA DiCo ("diversity covering") project that has not yet reached clinical trials [1].

\section{AMA-1 "Australia"}

In this project $E$. coli expressed AMA1 was adjuvanted with Montanide ISA 720. There were low anti-AMA1 antibody responses and only a few volunteers displayed $\mathrm{T}$ cell responses. The reactogenicity profile associated with Montanide ISA 720, including local pain and delayed injection site reactions, were also found in this study [147].

PfCP2.9 (MSP-1 19/AMA-1 chimera)

PfCP2.9 is a fusion protein containing domain III of AMA1 strain 3D7 and the $19 \mathrm{kDa}$ c-terminal portion of MSP1 strain K1/FVO, expressed in $P$. pastoris and adjuvanted with Montanide ISA 720. Two Phase 1a trials have assessed the safety, reactogenicity and immunogenicity of the vaccine construct at various dosage levels and vaccination schedules. The first 1 a trial, examining high doses of the vaccine, demonstrated high antiPfCP2.9 antibody titres but displayed some local reactogenicity [148]. The second Phase 1a trial, assessed the vaccine at lower doses and with wider gaps in the vaccination schedule. The antibody titres remained high with reduced reactogenicity, but GIA and IFA activity were suboptimal and the immunogenicity was markedly lower than seen in non-human primates [149].

\section{GLURP (85-213)}

Anti-GLURP antibodies have been associated with a reduced risk of clinical disease in those naturally exposed, and as with MSP3, cytophilic IgG subclasses are implicated in possible protection. A Phase 1a trial utilizing a GLURP long synthetic peptide adjuvanted with either aluminium hydroxide or Montanide ISA 720 showed both a strong cell-mediated and humoral response, especially for anti-GLURP IgG1. However, both formulations of the vaccine displayed a dosedependent increase in adverse events at the injection site and 7/18 volunteers in the ISA 720 group did not receive a third immunization due to predefined 
withdrawal criteria [150]. Evaluation of GLURP continues as part of the GMZ2 construct.

\section{Combination vaccines including multiple life-cycle stages NMRC-M3V-D/Ad-PfCA Prime/Boost \& NMRC-M3V-Ad-PfCA}

These approaches are DNA-based vaccination combining the CS pre-erythrocytic antigen with the AMA1 blood-stage antigen (now known also to also be expressed in other stages of the life-cycle). The initial strategy was to use DNA encoding CS and AMA1 proteins to prime, then boost with adenovirus 5 vectors expressing the same antigens. Publication of the results of the Phase 2a challenge study is awaited [151]. A Phase 1 trial was conducted in US with adenovirus 5 vectors encoding CS and AMA1. Very high frequencies of CD8+ T cells were induced [152], but no sterile protection was afforded in a follow-on Phase 2a trial using the CS component alone [153]. These approaches confirm the promise of Ad5 for induction of CD8 responses in humans. Some refinements to this approach are in pre-clinical development [1].

\section{CS, AMA1 virosomes (PEV301,302)}

Synthetic peptides were manufactured representing fragments of malaria proteins thought to be good immune targets. These are displayed as phospatidylethanolamine (PE)-peptide conjugates on the surface of IRIVs (immunopotentiating reconstituted influenza virosomes). PEV301 is the virosome with the synthetic CS protein conjugate UK39, and PEV302 virosome has the synthetic AMA1 protein conjugate AMA149-C1. IRIVs have already been used for licensed influenza and hepatitis $\mathrm{A}$ vaccines and, in various guises, can deliver multiple antigens to focus on CD4, CD8 $\mathrm{T}$ cell or antibody responses. A Phase 1a study in healthy malaria naïve adults demonstrated that volunteers immunized with a mix of both PEV301 and PEV302 developed antiAMA149-C1 and anti-UK39 antibody titres [154]. Further immunogenicity studies on the PEV301 portion of the vaccine revealed induced in vitro inhibition of sporozoite migration and hepatocyte invasion [155]. In a Phase 2a experimental sporozoite challenge trial in malaria non-immune Caucasian volunteers, vaccinerelated partial but modest protection against sporozoite challenge was observed in terms of a delay in time to parasitaemia [156], although no sterile protection was observed. A recently completed Phase $1 \mathrm{~b}$ vaccine trial in semi-immune Tanzanian adults and children confirmed the safety and immunogenicity of the platform. In addition, an exploratory analysis showed a reduced incidence of clinical episodes of malaria. Whilst interesting this requires confirmation in field efficacy studies [157]. There has been a change of ownership of the biotech company with potential implications for the future application of this promising technology to malaria.

\section{Discontinued combination vaccines including multiple life-cycle stages Spf66}

Spf66 is a vaccine candidate developed in Colombia in the late 1980s. It is a synthetic peptide consisting of CS and merozoite surface protein 1 (MSP1) epitopes adjuvanted with alum, and more recently tested with QS-21. Several studies in multiple Phases and countries have assessed this vaccine and while overall the vaccine was felt to be safe, the immunogenicity and vaccine efficacy have been relatively low [158]. Phase 3 studies in South America reported a vaccine efficacy of $28 \%$ (95\%CI 18 37) for clinical malaria [159], but the African and Asian studies taken together failed to show useful efficacy for this vaccine [160-169]. There was much debate about the interpretation of the South American results because of the many differences in trial design between the first studies and those in Africa and Asia. This is an important example of the fact that malaria field efficacy data should be obtained using standardized consensus case definitions, endpoints and trial designs in a variety of epidemiological settings among various age groups, and then be applied only to the settings and age groups in which it was obtained, because of the major heterogeneities of malaria epidemiology, immunity and vaccine efficacy. When vaccine efficacy varies from trial to trial, manufacturing consistency between vaccine lots could be a contributory factor.

\section{RTS,S/ASO2 (CS) and FMP-1/ASO2 (MSP1)}

Combination of RTS,S with other promising approaches has long been one stated aim of the RTS,S development programme. In this Phase $1 / 2$ a trial, researchers concomitantly administered FMP-1/AS02 and RTS,S/AS02A. Efficacy of RTS,S/AS02 was similar in co-administration with FMP1/AS02 compared to RTS,S alone. This indicated that there was no detectable immunological interference between the two components, and that FMP1 gave no protection in the challenge model as detected by microscopy [170].

\section{Sexual stage vaccines}

Currently there are a few sexual stage vaccines in preclinical development and at least one Phase 1 trial is underway. As the vaccines are intended to block the life-cycle in Anopheline mosquitoes, vaccine efficacy needs to be measured as a reduction in community level transmission of malaria, through cluster randomized trials. Due to the logistic challenges with conducting large cluster randomized trials, the availability of data for decision-making earlier in the development pathway could greatly facilitate progress with these vaccines. Intermediate proof-of-principle efficacy trials may be possible with the emphasis on demonstrating a reduction in infectivity of humans for mosquitoes. A valuable membrane-feeding assay (MFA) enables 
investigators to assess the ability of sera raised against sexual stage antigens to reduce infection of mosquitoes on exposure to gametocyte-infected blood, but the link between immune responses in individuals and effect on transmission is not known. Efforts to qualify, and if possible to validate, this assay will be important for vaccine development.

Given the disappointing results of many blood stage vaccine projects, and the emphasis on malaria eradication as a long-term aim by some funders, sexual and mosquito stage vaccine $R \& D$ funding may well increase over the next 5-10 years.

Previous clinical trials of sexual stage vaccines that have been discontinued involve ookinete antigens Pfs 25 from $P$. falciparum and Pvs 25 from $P$. vivax. Phase 1 studies examined the antibody response to the vaccine as well as activity in MFA. Saccharomyces cerevisiae expressed Pvs25, adjuvanted with alhydrogel, elicited low titre anti-Pvs25 antibodies and little transmission blocking activity [171]. A second Phase 1 study examining Pvs25 and Pfs 25 adjuvanted with Montanide ISA 51 induced some antibody response and transmission blocking activity. The study was stopped due to unacceptable reactogenicity most likely related to the adjuvant [172]. In both studies and in pre-clinical work by the same group there is a consistent correlation between titre of anti-Pfs 25 antibody and MFA activity [173].

Two of the sexual stage vaccine projects in preclinical development are based on the Pfs 25 antigen. Preclinical studies in mice have shown that when Pfs 25 is chemically conjugated to recombinant Pseudomonas aeruginosa ExoProtein A (EPA) and adjuvanted with alhydrogel, both the anti-Pfs 25 antibody response and transmission blocking activity are significantly higher than with Pfs25/alhydrogel alone [174,175]. A Phase 1 clinical trial of this vaccine candidate began in the latter part of 2011 [176]. Given that sexual stage and mosquito antigen vaccines will need to be administered across a wide age range commensurate with the human infectious reservoir in each setting, robust safety is a key feature of the desired target product profile. It is therefore highly encouraging that the pre-clinical studies with Pfs25-EPA indicate that alhydrogel may be sufficient as an adjuvant. Avoiding the many challenges associated with novel adjuvants, where possible, may be advisable for this group of vaccines.

Preclinical studies examining multimeric Pfs25 selfconjugates also showed an increase in anti-Pfs25 antibody levels and reduction of oocyst numbers in the mosquito midgut [13].

\section{Plasmodium vivax vaccine projects}

Control of mosquito vectors that support $P$. vivax has proven more challenging than $P$. falciparum in many settings, and $P$. vivax transmission may persist after $P$. falciparum has been eliminated because of its capacity to cause relapse from hypnozoites in the liver. Field trial design is complicated by the fact that $P$. vivax vaccine evaluation will most likely occur in co-endemic settings and the fact that distinguishing hypnozoite reactivation from new infections is not straightforward. Additionally the sporozoite challenge model is less well established for $P$. vivax, partly because culture of $P$. vivax gametocytes is problematic.

As with sexual stage and mosquito antigen projects, $P$. vivax is likely to receive additional $R \& D$ funding in the next 5-10 year cycle, particularly if $P$. falciparum transmission, morbidity and mortality continue to fall. Thus although there is a little clinical activity to report now, this is likely to change [177].

\section{VMP001/ASO1B}

VMP001/AS01B is currently the only vaccine in clinical evaluation that is designed to protect against $P$. vivax. In contrast to $P$. falciparum, the immunodominant $\mathrm{B}$ cell epitopes exhibit dimorphism in P. vivax. VMP001 includes the repeat region from the two alleles (VK210 and VK247) as well as $\mathrm{N}$ and C terminal fragments. It is an $E$. coli expressed recombinant protein adjuvanted with AS01. A Phase 1/2a challenge trial occurred in US volunteers at the end of 2010 [14].

\section{Discussion and Conclusion}

Over two decades on from the first clinical trials of vaccines for malaria, much has been learned about the pipeline from discovery research in the laboratory to successful conduct and analysis of large-scale field studies (see table 1), and one product is undergoing Phase 3 studies with a view to licensure. In this period, substantial progress has been made in evaluating many antigens and scientists have learned much about the need to meet requirements of developers in establishing clear product profiles.

Compared with other infectious diseases of major global importance such as HIV and tuberculosis, malaria vaccine research is facilitated by the availability of a clinical challenge model and a high attack rate in endemic areas, enabling definitive assessment by human experimentation for vaccines that prevent infection. There is consensus for testing the efficacy of pre-erythrocytic vaccines in sporozoite challenge studies, and an emerging consensus that some evidence of effect as evidenced by a degree of sterile protection or at least a reduced parasite growth rate is required as a pre-condition for moving asexual stage vaccines to expensive large-scale clinical trials, as other measures such as growth-inhibitory assays have yet to fulfill their promise as surrogate markers of protection. WHO is facilitating a harmonization process for sporozoite challenge trials 
Table 1 Lessons learned in terms of safety, immunogenicity, efficacy and trial methodology from malaria vaccine research over the last 5-10 years

\begin{tabular}{|c|c|}
\hline \multirow[t]{3}{*}{ Safety } & $\begin{array}{l}\text { Reactogenicity is higher with water-in-oil emulsions (e.g. ISA 720) when compared to marketed adjuvants (alhydrogel) or a } \\
\text { marketed virosomal platform. }\end{array}$ \\
\hline & $\begin{array}{l}\text { Safety and reactogenicity in semi-immune populations living in endemic areas has not been higher than in naïve populations, and } \\
\text { is often lower. }\end{array}$ \\
\hline & Safety and reactogenicity in young children has not been worse than in adult populations \\
\hline \multirow[t]{4}{*}{ Immunogenicity } & DNA alone is poorly immunogenic \\
\hline & $\begin{array}{l}\text { Oil in water emulsions (AS01, AS02) and water in oil emulsions (ISA 720, ISA51) are more immunogenic than alhydrogel for } \\
\text { recombinant monomeric protein }\end{array}$ \\
\hline & In general, there is little induction of CD8 cells in humans (with the exception of certain adenovirus containing regimens) \\
\hline & In general, there has been little clinically significant interference between the malarial antigen and EPI vaccine antigens \\
\hline \multirow[t]{3}{*}{ Efficacy } & Only RTS,S-based vaccines have repeatedly shown efficacy to reduce morbidity in endemic areas \\
\hline & $\begin{array}{l}\text { Highly polymorphic blood-stage antigens have tended to lead to allele-specific efficacy, but poor efficacy against the population } \\
\text { of circulating strains }\end{array}$ \\
\hline & Multiple episodes of malaria takes priority over time to first episode for public health assessment in clinical malaria vaccine trials. \\
\hline \multirow[t]{6}{*}{ Methodology } & $\begin{array}{l}\text { Demonstration of effect in in vitro studies (growth-inhibition assay in particular) or animal studies have not been shown to } \\
\text { correlate well with efficacy results in the field }\end{array}$ \\
\hline & Human challenge studies (Phase Ila trials) have been validated for the screening of pre-erythrocytic vaccines by the RTS,S results \\
\hline & $\begin{array}{l}\text { It is agreed that every Phase IIb/III vaccine trial design includes a commercialized vaccine that will benefit the control group as } \\
\text { comparator and that any trial subject receives at least the standard package of preventive measures (LLIN and others) } \\
\text { implemented in the country. }\end{array}$ \\
\hline & $\begin{array}{l}\text { Methodological and ethical issues would arise in testing of new malaria vaccines in the field if a licensed malaria vaccine had } \\
\text { become a standard preventive measure in a given setting. }\end{array}$ \\
\hline & $\begin{array}{l}\text { Methodological and feasibility issues are arising to test new vaccines in the field because malaria morbidity is considerably } \\
\text { decreasing in areas where trial sites are in place. }\end{array}$ \\
\hline & $\begin{array}{l}\text { There is as yet no formal trial design to assess the efficacy of sexual stage and mosquito antigen vaccines prior to large scale } \\
\text { cluster randomized trials; specific baseline epidemiological studies are required for sample size calculations and trial design for } \\
\text { possible Phase llb trials in this area }\end{array}$ \\
\hline
\end{tabular}

with consensus Standard Operating Procedures and documents available to guide design and conduct of such trials.

There is now consensus on many of the case definitions, endpoints and best analytical methods for measurement of reduction of morbidity conferred by preerythrocytic vaccines [178]. WHO has requested that data on multiple episodes of malaria, and time at risk, is presented divided into time periods to enable evaluation of long-term follow-up data [179], as impact on multiple episodes of malaria is the most important clinical/outpatient malaria endpoint from the public health and policy perspective. Methodological areas which remain the subject of ongoing work include: statistical methods for examining the duration of protection of vaccines taking into account the major but unmeasured heterogeneities of risk; case definitions and endpoints for blood-stage vaccine efficacy trials; trial designs for evaluation of reduction in infectivity of humans for mosquitoes.

Profiles for products targeted to reduce the global burden of malaria have focused on the desirability of reducing mortality and morbidity in vulnerable groups of young children and pregnant women [180] living in endemic areas, whereas targets for military and traveler populations focus on complete prevention of infection, even for relatively short periods after vaccination. It is highly likely that different immune mechanisms operate to prevent infection or modify disease but in neither case is the critical protective immune response for these target groups known or understood. Promising effects of RTS,S have encouraged investigators and funding agencies to raise the longer term target product threshold efficacy to the order of $80 \%$ for second generation products, yet still with a longer term "gold standard" aim for complete protection from clinical disease.

More recently, thanks to some successful malaria reduction campaigns in parts of Africa and the critical advocacy of Bill and Melinda Gates, the malaria community is considering the research and other requirements for a strategy leading to eventual eradication of malaria [11]. Of course this has always been seen as the ultimate goal but priority in the past four decades has been given to reducing the disease burden in regions with highest endemicity. The re-emergence of debate on eradication has not reduced the priority that scientists give to vaccines for potential impact, but has caused vaccines to be seen through another lens for their potential to reduce disease transmission. Vaccines 
directed against any stages of the parasite could have impact on transmission, with sexual stage vaccines targeting only this activity, and vaccines against mosquito gut having similar potential.

There was some concern two decades ago that vaccines designed to prevent immunity in travelers or the military may be of limited benefit to children of endemic areas since immunity against malaria is known to be species and stage specific. It is believed that a preerythrocytic vaccine designed to prevent infection in a non-immune individual would need to be highly effective for impact (well over $80 \%$ sterile protection) since a single parasite reaching the blood stream could lead to lethal infection. This however may not be true for semiimmune individuals when an effect of reducing the burden of parasites reaching the bloodstream may be of benefit in reducing uncomplicated malaria and severe morbidity. The better than expected effects of RTS,S vaccine in children of endemic areas support this hypothesis, and suggest that this vaccine could be achieving in some of the population the desired goal of converting the immune status of infants of endemic areas from that of a newborn to that of a three year old child who is protected, albeit incompletely, from clinical disease despite recurrent infection (concomitant immunity).

Early success with the pre-erythrocytic vaccine RTS,S and the call for malaria eradication have led some funders to reduce priority and funding for vaccines directed against blood stages. Most in the field argue that the considerable evidence for protection directed against blood stages, such as passive transfer experiments, validate the approach of seeking to combine the best candidates from more than one stage. A major consideration is to determine criteria for advancing particular candidates.

Various factors have been used to decide on moving candidates to clinical trials but as none has proved reliable, better ways of making this assessment and downselection are needed. Animal models are not optimal and immune responses in rodents or non-human primates have not so far proved to be reliable indicators. Highly variable antigens with multiple alleles are obviously targets of the immune response under natural challenge, and vaccine studies of AMA-1 and MSP 2 suggest that allele-specific effects can be achieved. However, the task of making a construct that would induce protection against a multitude of variants could be insurmountable. On the other hand, invariant antigens that are critical for invasion could be good targets if they could be made immunogenic. There is growing consensus that in order to progress an antigen to field trial stage, there is a requirement for the candidate to have demonstrable impact on parasite growth in non- immune individuals. Recent advances in antigen delivery systems using viral like particles, novel adjuvants, and alternate delivery systems, such as recombinant viral delivery and heterologous prime boosting have demonstrated capacity to induce effective responses that are not seen following natural infection and treatment or recovery.

Advances in technology have now provided proof of principle (in other systems as well as malaria) that the combination of priming with DNA and boosting by viral delivery, or priming and boosting with two different viral delivery systems can induce protection in a proportion of individuals. Studies of protected and non-protected individuals may enhance understanding of the critical immune response and give a guide to correlates of protection that may then potentially be inducible with simpler regimens. Malaria vaccine researchers follow developments in HIV and tuberculosis with great interest, considering the similar challenges of understanding the non-sterilising clinical immunity that occurs at stages of these three diseases. All share the goal of understanding mechanisms for inducing longlived immunological memory and how new and improved technologies could achieve this goal

With regard to adjuvant selection, the ICC-1132 project described in this review [65-68] serves as a useful case study of some general points. First, alum-adjuvantation has been repeatedly demonstrated to be inadequate for inducing the desired response to monomeric recombinant malaria proteins. However if alum-adjuvantation were to be sufficient in specific cases this would probably represent the best adjuvant approach in many ways, and there is some hope that with increased immunogenicity of protein conjugation or particulate technologies, alum-adjuvantation might suffice in some cases. Secondly, promising immunogenicity in mice, as was seen with ICC-1132, has often not translated to the clinic. Thirdly the strongest clinical experience with adjuvants is with GSK's proprietary adjuvants such as AS02 and AS01. Given the issues with access to these proprietary adjuvants, groups have often opted for use of water-in-oil adjuvants such as ISA 720 or ISA 51 and these tend to give good results in pre-clinical experiments. However, an unfavourable combination of issues with chemical modification of antigens that can compromise stability, a lack of consistency for bedside formulation and at times unacceptable local reactogenicity have tended to terminate development of many waterin-oil formulations in the malaria field. There is sufficient experience with these water-in-oil emulsions now to recommend alternate formulations. Thus access to sufficiently potent adjuvants suitable for clinical use and without proprietary limitations remains a key rate-limiting factor in malaria vaccine development. 
Many lessons have been learned about the long process of establishing field trial sites, gaining regulatory approval, establishing Ethics Committees, and completing analysis. Incidence of malaria invariably falls with the intensive surveillance required for clinical analysis in well-monitored field sites and trial sample sizes are necessarily increased considering the decreased incidence of malaria for test and control groups, when gold standard control measures are applied for all participants. In addition, malaria transmission has fallen in the region of several field trial sites, probably due to the success of national malaria control programmes. Investigators have recognized the need to be prepared to increase the duration or geographical scope to achieve the required numbers of enrolments. It is essential to develop local regulatory and ethics capacity for local trials. Communication is critical for informing participants and communities about the goals of studies that in many cases would be better described as "experimental medicine" or "trials in humans" rather than "vaccine trials", in order not to raise artificially high expectations of outcomes. Establishing these basic supports is very important for the large number of future trials to examine various combinations and the duration of efficacy. So far there has been no evidence of disease enhancement, but researchers must continue to be vigilant, and also be aware of potential rebound morbidity following temporary interruption of clinical infections.

Considering the devastating impact of the disease, global resource allocation has been modest, particularly now that the RTS,S success confirms that malaria vaccination can reduce paediatric morbidity in the field. In the years ahead it will be appropriate to aim for a vaccine with $80 \%$ or higher efficacy and substantial impact on transmission as envisaged by the malaria vaccine technology roadmap, as a 2025 goal, and malaria eradication R\&D agenda initiatives.

\section{Acknowledgements}

The views expressed are those of the authors and do not necessarily represent the views, position or policy of the World Health Organization. This manuscript was compiled as part of the Vaccine Experience at WHO (VIEW) internship, funded by Johns Hopkins Bloomberg School of Public Health. We acknowledge the helpful input of two unnamed peer-reviewers This manuscript would not be possible without the extensive support and information-sharing of the Malaria Vaccine Funders Group and malaria vaccine sponsors and investigators around the world, to maintain the WHO rainbow table as a resource for the community.

\footnotetext{
Author details

'Initiative for Vaccine Research, Department of Immunization, Vaccines \& Biologicals, World Health Organization, Avenue Appia 20, 1211-CH 27, Geneva, Switzerland. ${ }^{2} J o h n s$ Hopkins Bloomberg School of Public Health, Johns Hopkins University, Baltimore, Maryland, USA. ${ }^{3}$ Nossal Institute for Global Health, University of Melbourne, Carlton, Victoria 3010, Australia. ${ }^{4}$ Infectious Disease Service \& Department of Ambulatory Care and Community Medicine, University Hospital, Lausanne, Switzerland. ${ }^{5}$ Swiss Tropical and Public Health Institute, University of Basel, Socinstrasse 57,
}

Postfach, 4002 Basel, Switzerland. ${ }^{6}$ Nuffield Department of Clinical Medicine, University of Oxford, John Radcliffe Hospital, OX3 9DU, Oxford, UK.

\section{Authors' contributions}

LS carried out the rainbow table update upon which this manuscript is based. LS obtained and read all key references, and clinical trial registry information. LS wrote the first draft of the manuscript. VM coordinated writing of the second and final drafts of the manuscript and revised the manuscript in response to reviewer's comments. GB and VM wrote the discussion and edited the second and final draft. BG edited and commented on the second and final drafts and compiled the table.

\section{Competing interests}

All authors declare that they have no competing financial interest. GB, BG and VM have previously acted as investigators on the following malaria vaccine trials: GB, Combination B trials in Papua New Guinea; BG, Phase Ib in Papua New Guinea adults. Phase llb in children of Combination B, Phase la and Ila of PfCS102 in adults in Switzerland, Phase la in Swiss adults and Ib in Tanzanian children and adults of the Pevion virosomes; VM, Phase la, Ila, Ib, Ilb of DNA/MVA and FP9/MVA ME-TRAP in Oxford and The Gambia.

Received: 3 October 2011 Accepted: 9 January 2012

Published: 9 January 2012

\section{References}

1. WHO: Malaria Vaccine Rainbow Tables.[http://www.who.int/ vaccine_research/links/Rainbow/en/index.html].

2. O'Meara WP, Mangeni JN, Steketee R, Greenwood B: Changes in the burden of malaria in sub-Saharan Africa. Lancet Infect Dis 2010, 10:545-555,

3. World Malaria Report 2010. [http://www.who.int/malaria].

4. Cohen S, McGregor IA, Carrington S: Gamma globulin and acquired immunity to malaria. Nature 1961, 192:733-737.

5. Bouharoun-Tayoun $H$, Attanath P, Sabchareon A, Chongsuphajaisiddhi T, Druilhe P: Antibodies that protect humans against Plasmodium falciparum blood stages do not on their own inhibit parasite growth and invasion in vitro, but act in cooperation with monocytes. J Exp Med 1990, 172:1633-1641.

6. Cochrane AH, Nussenzweig RS, Nardin EH: Immunization against sporozoites. In Malaria. Volume 3. Edited by: Kreier JP. New York Academic Press; 1980.

7. Clyde DF, Most H, McCarthy VC, Vanderberg JP: Immunization of man against sporozite-induced falciparum malaria. Am J Med Sci 1973, 266:169-177.

8. Malaria Vaccine Technology Roadmap Final Report. [http://www. malariavaccine.org/files/Malaria_Vaccine_TRM_Final_000.pdf].

9. Moran M, Guzman J, Ropars A, Jorgensen M, McDonald A, Potter S, HaileSelassie H: The malaria product pipeline: planning for the future London, UK: The George Institute for International Health; 2007.

10. Moorthy VS, Kieny MP: Reducing empiricism in malaria vaccine design. Lancet Infect Dis 2010, 10:204-211.

11. malERA Consultative Group on Vaccines: A research agenda for malaria eradication: vaccines. PLoS Med 2011, 8:e1000398.

12. MALVAC: Measures of efficacy of anti-malarial interventions against malaria transmission. 2010 [http://www.who.int/vaccine_research/ malaria_malvac2010/en/index.html].

13. Kubler-Kielb J, Majadly F, Biesova Z, Mocca CP, Guo C, Nussenzweig R, Nussenzweig V, Mishra S, Wu Y, Miller LH, Keith JM, Liu TY, Robbins JB, Schneerson R: A bicomponent Plasmodium falciparum investigational vaccine composed of protein-peptide conjugates. Proc Natl Acad Sci USA 2010, 107:1172-1177.

14. Study of VMP001 and AS01B in Healthy Malaria-Naive Adults. [http:// clinicaltrials.gov/ct2/show/NCT01157897].

15. Langhorne J, Ndungu FM, Sponaas AM, Marsh K: Immunity to malaria: more questions than answers. Nat Immunol 2008, 9:725-732.

16. Coppi A, Natarajan R, Pradel G, Bennett BL, James ER, Roggero MA, Corradin G, Persson C, Tewari R, Sinnis P: The malaria circumsporozoite protein has two functional domains, each with distinct roles as sporozoites journey from mosquito to mammalian host. J Exp Med 2011, 208:341-356. 
17. Zavala F, Tam JP, Hollingdale MR, Cochrane AH, Quakyi I, Nussenzweig RS, Nussenzweig $\mathrm{V}$ : Rationale for development of a synthetic vaccine against Plasmodium falciparum malaria. Science 1985, 228:1436-1440.

18. John CC, Tande AJ, Moormann AM, Sumba PO, Lanar DE, Min XM, Kazura JW: Antibodies to pre-erythrocytic Plasmodium falciparum antigens and risk of clinical malaria in Kenyan children. J Infect Dis 2008, 197:519-526.

19. Nussenzweig RS, Nussenzweig $V$ : Antisporozoite vaccine for malaria: experimental basis and current status. Rev Infect Dis 1989, 11(Suppl 3):579-585.

20. Cohen J, Nussenzweig V, Nussenzweig R, Vekemans J, Leach A: From the circumsporozoite protein to the RTS,S/AS candidate vaccine. Hum Vaccin 2009, 6:90-96.

21. Ballou WR: The development of the RTS,S malaria vaccine candidate: challenges and lessons. Parasite Immunol 2009, 31:492-500.

22. Casares S, Brumeanu TD, Richie TL: The RTS,S malaria vaccine. Vaccine 2010, 28:4880-4894.

23. Olotu A, Lusingu J, Leach A, Lievens M, Vekemans J, Msham S, Lang T, Gould J, Dubois MC, Jongert E, Vansadia P, Carter T, Njuguna P, Awuondo KO, Malabeja A, Abdul O, Gesase S, Mturi N, Drakeley CJ, Savarese B, Villafana T, Lapierre D, Ballou WR, Cohen J, Lemnge MM, Peshu N, Marsh K, Riley EM, von Seidlein L, Bejon P: Efficacy of RTS,S/ AS01E malaria vaccine and exploratory analysis on anti-circumsporozoite antibody titres and protection in children aged 5-17 months in Kenya and Tanzania: a randomised controlled trial. Lancet Infect Dis 2011, 11:102-109.

24. Olotu A, Moris P, Mwacharo J, Vekemans J, Kimani D, Janssens M, Kai O, Jongert E, Lievens M, Leach A, Villafana T, Savarese B, Marsh K, Cohen J, Bejon P: Circumsporozoite-specific T cell responses in children vaccinated with RTS,S/ASO1(E) and protection against $P$. falciparum clinical malaria. PLoS One 2011, 6:e25786.

25. The RTS, S Clinical Trials Partnership: First results of 3 trial of RTS,S/AS01 malaria vaccine in African children. N Engl J Med 2011, 365:1863-1875.

26. White NJ: A vaccine for malaria. N Engl J Med 2011, 365:1926-1927.

27. Li S, Rodrigues M, Rodriguez D, Rodriguez JR, Esteban M, Palese P, Nussenzweig RS, Zavala F: Priming with recombinant influenza virus followed by administration of recombinant vaccinia virus induces CD8+ T-cell-mediated protective immunity against malaria. Proc Natl Acad SCi USA 1993, 90:5214-5218.

28. Shott JP, McGrath SM, Pau MG, Custers JH, Ophorst O, Demoitie MA, Dubois MC, Komisar J, Cobb M, Kester KE, Dubois P, Cohen J, Goudsmit J, Heppner DG, Stewart VA: Adenovirus 5 and 35 vectors expressing Plasmodium falciparum circumsporozoite surface protein elicit potent antigen-specific cellular IFN-gamma and antibody responses in mice. Vaccine 2008, 26:2818-2823.

29. Adenovirus Vaccine for Malaria. [http://clinicaltrials.gov/ct2/show/ NCT00371189]

30. Adenovirus Type 35 Based Circumsporozoite Malaria Vaccine in Burkina Faso. [http://clinicaltrials.gov/ct2/show/NCT01018459].

31. Thorner AR, Vogels R, Kaspers J, Weverling GJ, Holterman L, Lemckert AA, Dilraj A, McNally LM, Jeena PM, Jepsen S, Abbink P, Nanda A, Swanson PE, Bates AT, O'Brien KL, Havenga MJ, Goudsmit J, Barouch DH: Age dependence of adenovirus-specific neutralizing antibody titers in individuals from sub-Saharan Africa. J Clin Microbiol 2006, 44:3781-3783.

32. Buchbinder SP, Mehrotra DV, Duerr A, Fitzgerald DW, Mogg R, Li D, Gilbert PB, Lama JR, Marmor M, Del Rio C, McElrath MJ, Casimiro DR, Gottesdiener KM, Chodakewitz JA, Corey L, Robertson MN: Efficacy assessment of a cell-mediated immunity HIV-1 vaccine (the Step Study): a double-blind, randomised, placebo-controlled, test-of-concept trial. Lancet 2008, 372:1881-1893.

33. Stewart VA, McGrath SM, Dubois PM, Pau MG, Mettens P, Shott J, Cobb M, Burge JR, Larson D, Ware LA, Demoitie MA, Weverling GJ, Bayat B, Custers JH, Dubois MC, Cohen J, Goudsmit J, G HD Jr: Priming with an adenovirus 35-circumsporozoite protein (CS) vaccine followed by RTS,S/ AS01B boosting significantly improves immunogenicity to Plasmodium falciparum CS compared to that with either malaria vaccine alone. Infect Immun 2007, 75:2283-2290.

34. Safety, immunogenicity and efficacy against of a combined malaria vaccine in healthy malaria-naïve adults. [http://clinicaltrials.gov/ct2/show/ NCT01366534]
35. Schofield L, Ferreira A, Altszuler R, Nussenzweig V, Nussenzweig RS: Interferon-gamma inhibits the intrahepatocytic development of malaria parasites in vitro. J Immunol 1987, 139:2020-2025

36. Reyes-Sandoval A, Berthoud T, Alder N, Siani L, Gilbert SC, Nicosia A, Colloca S, Cortese R, Hill AV: Prime-boost immunization with adenoviral and modified vaccinia virus Ankara vectors enhances the durability and polyfunctionality of protective malaria CD8+ T-cell responses. Infect Immun 2010, 78:145-153.

37. Cowan G, Krishna S, Crisanti A, Robson K: Expression of thrombospondinrelated anonymous protein in Plasmodium falciparum sporozoites [letter]. Lancet 1992, 339:1412-1413.

38. Rogers WO, Malik A, Mellouk S, Nakamura K, Rogers MD, Szarfman A, Gordon DM, Nussler AK, Aikawa M, Hoffman SL: Characterization of Plasmodium falciparum sporozoite surface protein 2. Proc Natl Acad Sci USA 1992, 89:9176-9180.

39. Capone S, Reyes-Sandoval A, Naddeo M, Siani L, Ammendola V, Rollier CS, Nicosia A, Colloca S, Cortese R, Folgori A, Hill AV: Immune responses against a liver-stage malaria antigen induced by simian adenoviral vector AdCh63 and MVA prime-boost immunisation in non-human primates. Vaccine 29:256-265.

40. A Study of AdCh63 ME-TRAP Alone and With MVA ME-TRAP. [http:// clinicaltrials.gov/ct2/show/NCT00890019].

41. A study to assess the effectiveness of a new malaria vaccine candidate by infecting vaccinated volunteers with malaria parasites. [http:// clinicaltrials.gov/ct2/show/NCT00890760].

42. EP1300 Polyepitope DNA vaccine against Plasmodium falciparum malaria. [http://clinicaltrials.gov/ct2/show/NCT01169077].

43. Wang S, Zhang C, Zhang L, Li J, Huang Z, Lu S: The relative immunogenicity of DNA vaccines delivered by the intramuscular needle injection, electroporation and gene gun methods. Vaccine 2008, 26:2100-2110.

44. Laddy DJ, Yan J, Khan AS, Andersen H, Cohn A, Greenhouse J, Lewis M, Manischewitz J, King LR, Golding H, Draghia-Akli R, Weiner DB: Electroporation of synthetic DNA antigens offers protection in nonhuman primates challenged with highly pathogenic avian influenza virus. J Virol 2009, 83:4624-4630.

45. Sardesai NY, Weiner DB: Electroporation delivery of DNA vaccines: prospects for success. Curr Opin Immunol 2011, 23:421-429.

46. Vasan S, Hurley A, Schlesinger SJ, Hannaman D, Gardiner DF, Dugin DP, Boente-Carrera M, Vittorino R, Caskey M, Andersen J, Huang Y, Cox JH, Tarragona-Fiol T, Gill DK, Cheeseman H, Clark L, Dally L, Smith C, Schmidt C, Park HH, Kopycinski JT, Gilmour J, Fast P, Bernard R, Ho DD: In vivo electroporation enhances the immunogenicity of an HIV-1 DNA vaccine candidate in healthy volunteers. PLoS One 2011, 6:e19252

47. Hoffman SL, Goh LM, Luke TC, Schneider I, Le TP, Doolan DL, Sacci J, de la Vega P, Dowler M, Paul C, Gordon DM, Stoute JA, Church LW, Sedegah M, Heppner DG, Ballou WR, Richie TL: Protection of humans against malaria by immunization with radiation-attenuated Plasmodium falciparum sporozoites. J Infect Dis 2002, 185:1155-1164.

48. Hoffman SL, Billingsley PF, James E, Richman A, Loyevsky M, Li T, Chakravarty S, Gunasekera A, Chattopadhyay R, Li M, Stafford R, Ahumada A, Epstein JE, Sedegah M, Reyes S, Richie TL, Lyke KE, Edelman R, Laurens MB, Plowe CV, Sim BK: Development of a metabolically active, non-replicating sporozoite vaccine to prevent Plasmodium falciparum malaria. Hum Vaccin 2010, 6:97-106.

49. Pinder M, Moorthy VS, Akanmori BD, Genton B, Brown GV: MALVAC 2009: Progress and challenges with development of whole organism malaria vaccines for endemic countries. Vaccine 2009, 28:4695-4702.

50. Epstein JE, Tewari K, Lyke KE, Sim BK, Billingsley PF, Laurens MB, Gunasekera A, Chakravarty S, James ER, Sedegah M, Richman A, Velmurugan S, Reyes S, Li M, Tucker K, Ahumada A, Ruben AJ, Li T, Stafford R, Eappen AG, Tamminga C, Bennett JW, Ockenhouse CF, Murphy JR, Komisar J, Thomas N, Loyevsky M, Birkett A, Plowe CV, Loucq C, et al: Live attenuated malaria vaccine designed to protect through hepatic CD8+ T cell immunity. Science 2011, 334:475-480.

51. Experimental PfSPZ Vaccine in Adults Without Malaria. [http://clinicaltrials. gov/ct2/show/NCT01441167]

52. Maier AG, Braks JA, Waters AP, Cowman AF: Negative selection using yeast cytosine deaminase/uracil phosphoribosyl transferase in Plasmodium falciparum for targeted gene deletion by double crossover recombination. Mol Biochem Parasitol 2006, 150:118-121. 
53. VanBuskirk KM, O'Neill MT, De La Vega P, Maier AG, Krzych U, Williams J, Dowler MG, Sacci JB, Kangwanrangsan N, Tsuboi T, Kneteman NM, Heppner DG, Murdock BA, Mikolajczak SA, Aly AS, Cowman AF, Kappe SH: Preerythrocytic, live-attenuated Plasmodium falciparum vaccine candidates by design. Proc Natl Acad Sci USA 2009, 106:13004-13009.

54. Walther M, Thompson FM, Dunachie S, Keating S, Todryk S, Berthoud T, Andrews L, Andersen RF, Moore A, Gilbert SC, Poulton I, Dubovsky F, Tierney E, Correa S, Huntcooke A, Butcher G, Williams J, Sinden RE, Hill AV: Safety, immunogenicity, and efficacy of prime-boost immunization with recombinant poxvirus FP9 and modified vaccinia virus Ankara encoding the full-length Plasmodium falciparum circumsporozoite protein. Infect Immun 2006, 74:2706-2716.

55. Imoukhuede EB, Berthoud T, Milligan P, Bojang K, Ismaili J, Keating S, Nwakanma D, Keita S, Njie F, Sowe M, Todryk S, Laidlaw SM, Skinner MA, Lang T, Gilbert S, Greenwood BM, Hill AV: Safety and immunogenicity of the malaria candidate vaccines FP9 CS and MVA CS in adult Gambian men. Vaccine 2006, 24:6526-6533.

56. Miyahira Y, Garcia-Sastre A, Rodriguez D, Rodriguez JR, Murata K, Tsuji M, Palese P, Esteban M, Zavala F, Nussenzweig RS: Recombinant viruses expressing a human malaria antigen can elicit potentially protective immune CD8(+) responses in mice. Proc Natl Acad Sci USA 1998, 95:3954-3959.

57. Dunachie SJ, Walther M, Epstein JE, Keating S, Berthoud T, Andrews L, Andersen RF, Bejon P, Goonetilleke N, Poulton I, Webster DP, Butcher G, Watkins K, Sinden RE, Levine GL, Richie TL, Schneider J, Kaslow D, Gilbert SC, Carucci DJ, Hill AV: A DNA prime-modified vaccinia virus ankara boost vaccine encoding thrombospondin-related adhesion protein but not circumsporozoite protein partially protects healthy malaria-naive adults against Plasmodium falciparum sporozoite challenge. Infect Immun 2006, 74:5933-5942.

58. Dunachie SJ, Walther M, Vuola JM, Webster DP, Keating SM, Berthoud T, Andrews L, Bejon P, Poulton I, Butcher G, Watkins K, Sinden RE, Leach A, Moris P, Tornieporth N, Schneider J, Dubovsky F, Tierney E, Williams J, G HD, Gilbert SC, Cohen J, Hill AV: A clinical trial of prime-boost immunisation with the candidate malaria vaccines RTS,S/AS02A and MVA-CS. Vaccine 2006, 24:2850-2859.

59. Wang R, Doolan DL, Le TP, Hedstrom RC, Coonan KM, Charoenvit Y, Jones TR, Hobart P, Margalith M, Ng J, Weiss WR, Sedegah M, de Taisne C, Norman JA, Hoffman SL: Induction of antigen-specific cytotoxic T lymphocytes in humans by a malaria DNA vaccine. Science 1998, 282:476-480

60. Wang R, Epstein J, Baraceros FM, Gorak EJ, Charoenvit Y, Carucci DJ, Hedstrom RC, Rahardjo N, Gay T, Hobart P, Stout R, Jones TR, Richie TL, Parker SE, Doolan DL, Norman J, Hoffman SL: Induction of CD4(+) T celldependent CD8(+) type 1 responses in humans by a malaria DNA vaccine. Proc Natl Acad Sci USA 2001, 98:10817-10822.

61. Le TP, Coonan KM, Hedstrom RC, Charoenvit $Y$, Sedegah M, Epstein JE, Kumar S, Wang R, Doolan DL, Maguire JD, Parker SE, Hobart P, Norman J, Hoffman SL: Safety, tolerability and humoral immune responses after intramuscular administration of a malaria DNA vaccine to healthy adult volunteers. Vaccine 2000, 18:1893-1901.

62. Wang R, Richie TL, Baraceros MF, Rahardjo N, Gay T, Banania JG, Charoenvit Y, Epstein JE, Luke T, Freilich DA, Norman J, Hoffman SL: Boosting of DNA vaccine-elicited gamma interferon responses in humans by exposure to malaria parasites. Infect Immun 2005, 73:2863-2872.

63. Wang R, Epstein J, Charoenvit Y, Baraceros FM, Rahardjo N, Gay T, Banania JG, Chattopadhyay R, de la Vega P, Richie TL, Tornieporth N, Doolan DL, Kester KE, Heppner DG, Norman J, Carucci DJ, Cohen JD, Hoffman SL: Induction in Humans of CD8+ and CD4+ T cell and antibody responses by sequential immunization with malaria DNA and recombinant protein. J Immunol 2004, 172:5561-5569.

64. Epstein JE, Charoenvit $Y$, Kester KE, Wang R, Newcomer R, Fitzpatrick S, Richie TL, Tornieporth N, Heppner DG, Ockenhouse C, Majam V, Holland C, Abot E, Ganeshan H, Berzins M, Jones T, Freydberg CN, Ng J, Norman J, Carucci DJ, Cohen J, Hoffman SL: Safety, tolerability, and antibody responses in humans after sequential immunization with a PfCSP DNA vaccine followed by the recombinant protein vaccine RTS,S/AS02A. Vaccine 2004, 22:1592-1603.

65. Nardin EH, Oliveira GA, Calvo-Calle JM, Wetzel K, Maier C, Birkett AJ Sarpotdar P, Corado ML, Thornton GB, Schmidt A: Phase I testing of a malaria vaccine composed of hepatitis B virus core particles expressing Plasmodium falciparum circumsporozoite epitopes. Infect Immun 2004, 72:6519-6527.

66. Gregson AL, Oliveira G, Othoro C, Calvo-Calle JM, Thorton GB, Nardin E, Edelman R: Phase I trial of an alhydrogel adjuvanted hepatitis B core virus-like particle containing epitopes of Plasmodium falciparum circumsporozoite protein. PloS One 2008, 3:e1556.

67. Oliveira GA, Wetzel K, Calvo-Calle JM, Nussenzweig R, Schmidt A, Birkett A, Dubovsky F, Tierney E, Gleiter CH, Boehmer G, Luty AJ, Ramharter M, Thornton GB, Kremsner PG, Nardin EH: Safety and enhanced immunogenicity of a hepatitis B core particle Plasmodium falciparum malaria vaccine formulated in adjuvant Montanide ISA 720 in a phase I trial. Infect Immun 2005, 73:3587-3597.

68. Walther M, Dunachie S, Keating S, Vuola JM, Berthoud T, Schmidt A, Maier C, Andrews L, Andersen RF, Gilbert S, Poulton I, Webster D, Dubovsky F, Tierney E, Sarpotdar P, Correa S, Huntcooke A, Butcher G, Williams J, Sinden RE, Thornton GB, Hill AV: Safety, immunogenicity and efficacy of a pre-erythrocytic malaria candidate vaccine, ICC-1132 formulated in Seppic ISA 720. Vaccine 2005, 23:857-864.

69. Lopez JA, Weilenman C, Audran R, Roggero MA, Bonelo A, Tiercy JM, Spertini F, Corradin G: A synthetic malaria vaccine elicits a potent $C D 8(+)$ and CD4(+) T lymphocyte immune response in humans. Implications for vaccination strategies. Eur J Immunol 2001, 31:1989-1998.

70. Audran R, Lurati-Ruiz F, Genton B, Blythman HE, Ofori-Anyinam O, Reymond C, Corradin G, Spertini F: The synthetic Plasmodium falciparum circumsporozoite peptide PfCS102 as a malaria vaccine candidate: a randomized controlled phase I trial. PloS One 2009, 4:e7304.

71. Genton B, D'Acremont V, Lurati-Ruiz F, Verhage D, Audran R, Hermsen C, Wolters L, Reymond C, Spertini F, Sauerwein R: Randomized double-blind controlled Phase I/lla trial to assess the efficacy of malaria vaccine PfCS102 to protect against challenge with P. falciparum. Vaccine 2010, 28:6573-6580.

72. Moorthy VS, Imoukhuede EB, Keating S, Pinder M, Webster D, Skinner MA, Gilbert SC, Walraven G, Hill AV: Phase 1 evaluation of 3 highly immunogenic prime-boost regimens, including a 12-month reboosting vaccination, for malaria vaccination in gambian men. J Infect Dis 2004, 189:2213-2219.

73. Vuola JM, Keating S, Webster DP, Berthoud T, Dunachie S, Gilbert SC, Hill AV: Differential immunogenicity of various heterologous prime-boost vaccine regimens using DNA and viral vectors in healthy volunteers. J Immunol 2005, 174:449-455.

74. Webster DP, Dunachie S, Vuola JM, Berthoud T, Keating S, Laidlaw SM, McConkey SJ, Poulton I, Andrews L, Andersen RF, Bejon P, Butcher G, Sinden R, Skinner MA, Gilbert SC, Hill AV: Enhanced T cell-mediated protection against malaria in human challenges by using the recombinant poxviruses FP9 and modified vaccinia virus Ankara. Proc Natl Acad Sci USA 2005, 102:4836-4841.

75. Bejon P, Mwacharo J, Kai OK, Todryk S, Keating S, Lang T, Gilbert SC, Peshu N, Marsh K, Hill AV: Immunogenicity of the candidate malaria vaccines FP9 and modified vaccinia virus Ankara encoding the preerythrocytic antigen ME-TRAP in 1-6 year old children in a malaria endemic area. Vaccine 2006, 24:4709-4715.

76. Bejon P, Peshu N, Gilbert SC, Lowe BS, Molyneux CS, Forsdyke J, Lang T, Hill AV, Marsh K: Safety profile of the viral vectors of attenuated fowlpox strain FP9 and modified vaccinia virus Ankara recombinant for either of 2 preerythrocytic malaria antigens, ME-TRAP or the circumsporozoite protein, in children and adults in Kenya. Clin Infect Dis 2006, 42:1102-1110.

77. Bejon P, Kai OK, Mwacharo J, Keating S, Lang T, Gilbert SC, Peshu N, Marsh K, Hill AV: Alternating vector immunizations encoding preerythrocytic malaria antigens enhance memory responses in a malaria endemic area. Eur J Immunol 2006, 36:2264-2272.

78. Bejon P, Mwacharo J, Kai O, Mwangi T, Milligan P, Todryk S, Keating S, Lang T, Lowe B, Gikonyo C, Molyneux C, Fegan G, Gilbert SC, Peshu N, Marsh $\mathrm{K}$, Hill AV: A phase $2 \mathrm{~b}$ randomised trial of the candidate malaria vaccines FP9 ME-TRAP and MVA ME-TRAP among children in Kenya. PLOS Clin Trials 2006, 1:e29.

79. Bejon P, Ogada E, Mwangi T, Milligan P, Lang T, Fegan G, Gilbert SC, Peshu N, Marsh K, Hill AV: Extended follow-up following a phase $2 b$ randomized trial of the candidate malaria vaccines FP9 ME-TRAP and MVA ME-TRAP among children in Kenya. PloS One 2007, 2:e707. 
80. McConkey SJ, Reece WH, Moorthy VS, Webster D, Dunachie S, Butcher G, Vuola JM, Blanchard TJ, Gothard P, Watkins K, Hannan CM, Everaere S, Brown K, Kester KE, Cummings J, Williams J, Heppner DG, Pathan A, Flanagan K, Arulanantham N, Roberts MT, Roy M, Smith GL, Schneider J, Peto T, Sinden RE, Gilbert SC, Hill AV: Enhanced T-cell immunogenicity of plasmid DNA vaccines boosted by recombinant modified vaccinia virus Ankara in humans. Nat Med 2003, 9:729-735.

81. Moorthy VS, Imoukhuede EB, Milligan P, Bojang K, Keating S, Kaye P, Pinder M, Gilbert SC, Walraven G, Greenwood BM, Hill AS: A randomised, double-blind, controlled vaccine efficacy trial of DNA/MVA ME-TRAP against malaria infection in Gambian adults. PLoS Med 2004, 1:e33.

82. Moorthy VS, Pinder M, Reece WH, Watkins K, Atabani S, Hannan C, Bojang K, McAdam KP, Schneider J, Gilbert S, Hill AV: Safety and immunogenicity of DNA/modified vaccinia virus ankara malaria vaccination in African adults. J Infect Dis 2003, 188:1239-1244.

83. Prieur E, Gilbert SC, Schneider J, Moore AC, Sheu EG, Goonetilleke N, Robson KJ, Hill AV: A Plasmodium falciparum candidate vaccine based on a six-antigen polyprotein encoded by recombinant poxviruses. Proc Natl Acad Sci USA 2004, 101:290-295

84. Porter DW, Thompson FM, Berthoud TK, Hutchings CL, Andrews L, Biswas S, Poulton I, Prieur E, Correa S, Rowland R, Lang T, Williams J, Gilbert SC, Sinden RE, Todryk S, Hill AV: A human Phase I/lla malaria challenge trial of a polyprotein malaria vaccine. Vaccine 2011, 29:7514-7522.

85. Kurtis JD, Hollingdale MR, Luty AJ, Lanar DE, Krzych U, Duffy PE: Preerythrocytic immunity to Plasmodium falciparum: the case for an LSA-1 vaccine. Trends Parasitol 2001, 17:219-223.

86. Cummings JF, Spring MD, Schwenk RJ, Ockenhouse CF, Kester KE, Polhemus ME, Walsh DS, Yoon IK, Prosperi C, Juompan LY, Lanar DE, Krzych U, Hall BT, Ware LA, Stewart VA, Williams J, Dowler M, Nielsen RK, Hillier CJ, Giersing BK, Dubovsky F, Malkin E, Tucker K, Dubois MC, Cohen JD, Ballou WR, Heppner DG Jr: Recombinant Liver Stage Antigen-1 (LSA-1) formulated with AS01 or AS02 is safe, elicits high titer antibody and induces IFN-gamma/IL-2 CD4+ T cells but does not protect against experimental Plasmodium falciparum infection. Vaccine 2010, 28:5135-5144.

87. Safety and efficacy study of Plasmodium falciparum LSA-3 malaria vaccine. [http://clinicaltrials.gov/ct2/show/NCT00509158].

88. Nieman AE, de Mast Q, Roestenberg M, Wiersma J, Pop G, Stalenhoef A, Druilhe $P$, Sauerwein $R$, van der Ven A: Cardiac complication after experimental human malaria infection: a case report. Malar J 2009, 8:277.

89. Moorthy VS, Diggs C, Ferro S, Good MF, Herrera S, Hill AV, Imoukhuede EB, Kumar S, Loucq C, Marsh K, Ockenhouse CF, Richie TL, Sauerwein RW: Report of a consultation on the optimization of clinical challenge trials for evaluation of candidate blood stage malaria vaccines, 18-19 March 2009, Bethesda, MD, USA. Vaccine 2009, 27:5719-5725.

90. Collins WE, Jeffery GM: A retrospective examination of secondary sporozoite- and trophozoite-induced infections with Plasmodium falciparum: development of parasitologic and clinical immunity following secondary infection. Am J Trop Med Hyg 1999, 61:20-35.

91. Holder AA: The carboxy-terminus of merozoite surface protein 1: structure, specific antibodies and immunity to malaria. Parasitology 2009, 136:1445-1456.

92. Fowkes FJ, Richards JS, Simpson JA, Beeson JG: The relationship between anti-merozoite antibodies and incidence of Plasmodium falciparum malaria: A systematic review and meta-analysis. PLoS Med 2010, 7: e1000218.

93. Sheehy SH, Duncan CJ, Elias SC, Collins KA, Ewer KJ, Spencer AJ, Williams AR, Halstead FD, Moretz SE, Miura K, Epp C, Dicks MD, Poulton ID, Lawrie AM, Berrie E, Moyle S, Long CA, Colloca S, Cortese R, Gilbert SC, Nicosia A, Hill AV, Draper SJ: Phase la clinical evaluation of the Plasmodium falciparum blood-stage antigen MSP1 in ChAd63 and MVA vaccine vectors. Mol Ther 2011, 19:2269-2276.

94. A study of the safety and effectiveness of two new malaria Vaccines. [http://clinicaltrials.gov/ct2/show/NCT01003314].

95. Study to assess efficacy of new malaria vaccine candidates AdCh63 AMA1, MVA AMA1, AdCh63 MSP1, MVA MSP1, AdCh63 ME-TRAP \& MVA ME-TRAP. [http://clinicaltrials.gov/ct2/show/NCT01142765].

96. A study to determine the effects of an investigational malaria vaccine given to adults living in the United States. [http://clinicaltrials.gov/ct2/ show/NCT00666380].
97. Ogutu BR, Apollo OJ, McKinney D, Okoth W, Siangla J, Dubovsky F, Tucker K, Waitumbi JN, Diggs C, Wittes J, Malkin E, Leach A, Soisson LA, Milman JB, Otieno L, Holland CA, Polhemus M, Remich SA, Ockenhouse CF, Cohen J, Ballou WR, Martin SK, Angov E, Stewart VA, Lyon JA, Heppner DG, Withers MR: Blood stage malaria vaccine eliciting high antigen-specific antibody concentrations confers no protection to young children in Western Kenya. PLoS One 2009, 4:e4708.

98. Druilhe P, Spertini F, Soesoe D, Corradin G, Mejia P, Singh S, Audran R, Bouzidi A, Oeuvray C, Roussilhon C: A malaria vaccine that elicits in humans antibodies able to kill Plasmodium falciparum. PLoS Med 2005, 2: e344.

99. Audran R, Cachat M, Lurati F, Soe S, Leroy O, Corradin G, Druilhe P, Spertini F: Phase I malaria vaccine trial with a long synthetic peptide derived from the merozoite surface protein 3 antigen. Infect Immun 2005, 73:8017-8026.

100. Sirima SB, Nebie I, Ouedraogo A, Tiono AB, Konate AT, Gansane A, Derme Al, Diarra A, Ouedraogo A, Soulama I, Cuzzin-Ouattara N, Cousens S, Leroy O: Safety and immunogenicity of the Plasmodium falciparum merozoite surface protein-3 long synthetic peptide (MSP3-LSP) malaria vaccine in healthy, semi-immune adult males in Burkina Faso, West Africa. Vaccine 2007, 25:2723-2732.

101. Nebie I, Diarra A, Ouedraogo A, Tiono AB, Konate AT, Gansane A, Soulama I, Cousens S, Leroy O, Sirima SB: Humoral and cell-mediated immunity to MSP3 peptides in adults immunized with MSP3 in malaria endemic area, Burkina Faso. Parasite Immunol 2009, 31:474-480.

102. Lusingu JP, Gesase S, Msham S, Francis F, Lemnge M, Seth M, Sembuche S, Rutta A, Minja D, Segeja MD, Bosomprah S, Cousens S, Noor R, Chilengi R, Druilhe P: Satisfactory safety and immunogenicity of MSP3 malaria vaccine candidate in Tanzanian children aged 12-24 months. Malar J 2009, 8:163.

103. Sirima SB, Tiono AB, Ouedraogo A, Diarra A, Ouedraogo AL, Yaro JB, Ouedraogo E, Gansane A, Bougouma EC, Konate AT, Kabore Y, Traore A, Chilengi R, Soulama I, Luty AJ, Druilhe P, Cousens S, Nebie I: Safety and immunogenicity of the malaria vaccine candidate MSP3 long synthetic peptide in 12-24 months-old Burkinabe children. PloS One 2009, 4:e7549.

104. Immunogenicity, efficacy and safety study of an MSP3-LSP (Long Synthetic Peptide) malaria vaccine. [http://clinicaltrials.gov/ct2/show/ NCT00652275].

105. Sirima SB, Cousens S, Druilhe P: Protection against malaria by MSP3 candidate vaccine. N Engl J Med 2011, 365:1062-1064.

106. Courtin D, Oesterholt M, Huismans H, Kusi K, Milet J, Badaut C, Gaye O, Roeffen W, Remarque EJ, Sauerwein R, Garcia A, Luty AJ: The quantity and quality of African children's IgG responses to merozoite surface antigens reflect protection against Plasmodium falciparum malaria. PloS One 2009, 4:e7590.

107. Udhayakumar V, Kariuki S, Kolczack M, Girma M, Roberts JM, Oloo AJ, Nahlen BL, Lal AA: Longitudinal study of natural immune responses to the Plasmodium falciparum apical membrane antigen (AMA-1) in a holoendemic region of malaria in western Kenya: Asembo Bay Cohort Project VIII. Am J Trop Med Hyg 2001, 65:100-107.

108. Takala SL, Plowe CV: Genetic diversity and malaria vaccine design, testing and efficacy: preventing and overcoming 'vaccine resistant malaria'. Parasite Immunol 2009, 31:560-573.

109. Polhemus ME, Magill AJ, Cummings JF, Kester KE, Ockenhouse CF, Lanar DE, Dutta S, Barbosa A, Soisson L, Diggs CL, Robinson SA, Haynes JD, Stewart VA, Ware LA, Brando C, Krzych U, Bowden RA, Cohen JD, Dubois MC, Ofori-Anyinam O, De-Kock E, Ballou WR, Heppner DG Jr: Phase I dose escalation safety and immunogenicity trial of Plasmodium falciparum apical membrane protein (AMA-1) FMP2.1, adjuvanted with AS02A, in malaria-naive adults at the Walter Reed Army Institute of Research. Vaccine 2007, 25:4203-4212.

110. Thera MA, Doumbo OK, Coulibaly D, Diallo DA, Kone AK, Guindo AB, Traore K, Dicko A, Sagara I, Sissoko MS, Baby M, Sissoko M, Diarra I, Niangaly A, Dolo A, Daou M, Diawara SI, Heppner DG, Stewart VA, Angov E, Bergmann-Leitner ES, Lanar DE, Dutta S, Soisson L, Diggs CL, Leach A, Owusu A, Dubois MC, Cohen J, Nixon JN, Gregson A, Takala SL, Lyke KE, Plowe CV: Safety and immunogenicity of an AMA-1 malaria vaccine in Malian adults: results of a phase 1 randomized controlled trial. PloS One 2008, 3:e1465.

111. Lyke KE, Daou M, Diarra I, Kone A, Kouriba B, Thera MA, Dutta S, Lanar DE, Heppner DG, Doumbo OK, Plowe CV, Sztein MB: Cell-mediated immunity 
elicited by the blood stage malaria vaccine apical membrane antigen 1 in Malian adults: results of a Phase I randomized trial. Vaccine 2009, 27:2171-2176.

112. Thera MA, Doumbo OK, Coulibaly D, Laurens MB, Kone AK, Guindo AB, Traore K, Sissoko M, Diallo DA, Diarra I, Kouriba B, Daou M, Dolo A, Baby M, Sissoko MS, Sagara I, Niangaly A, Traore I, Olotu A, Godeaux O, Leach A, Dubois MC, Ballou WR, Cohen J, Thompson D, Dube T, Soisson L, Diggs CL, Takala SL, Lyke KE, House B, Lanar DE, Dutta S, Heppner DG, Plowe CV: Safety and immunogenicity of an AMA1 malaria vaccine in Malian children: results of a phase 1 randomized controlled trial. PLOS One 2009, 5:e9041.

113. Thera MA, Doumbo OK, Coulibaly D, Laurens MB, Ouattara A, Kone AK, Guindo AB, Traore K, Traore I, Kouriba B, Diallo DA, Diarra I, Daou M, Dolo A, Tolo Y, Sissoko MS, Niangaly A, Sissoko M, Takala-Harrison S, Lyke KE, Wu Y, Blackwelder WC, Godeaux O, Vekemans J, Dubois MC, Ballou WR, Cohen J, Thompson D, Dube T, Soisson L, Diggs CL, House B, Lanar DE, Dutta S, Heppner DG, Plowe CV: A field trial to assess a bloodstage malaria vaccine. N Engl J Med 2011, 365:1004-1013.

114. Spring MD, Cummings JF, Ockenhouse CF, Dutta S, Reidler R, Angov E, Bergmann-Leitner E, Stewart VA, Bittner S, Juompan L, Kortepeter MG, Nielsen R, Krzych U, Tierney E, Ware LA, Dowler M, Hermsen CC, Sauerwein RW, de Vlas SJ, Ofori-Anyinam O, Lanar DE, Williams JL, Kester KE, Tucker K, Shi M, Malkin E, Long C, Diggs CL, Soisson L, Dubois M-C, Ballou WR, Cohen J, Heppner DG Jr: Phase 1/2a study of the malaria vaccine candidate Apical Membrane Antigen-1 (AMA-1) administered in adjuvant system AS01B or AS02A. PLoS One 2009, 4:e5254.

115. Mullen GE, Ellis RD, Miura K, Malkin E, Nolan C, Hay M, Fay MP, Saul A, Zhu D, Rausch K, Moretz S, Zhou H, Long CA, Miller LH, Treanor J: Phase 1 trial of AMA1-C1/Alhydrogel plus CPG 7909: an asexual blood-stage vaccine for Plasmodium falciparum malaria. PloS One 2008, 3:e2940.

116. Sagara I, Ellis RD, Dicko A, Niambele MB, Kamate B, Guindo O, Sissoko MS, Fay MP, Guindo MA, Kante O, Saye R, Miura K, Long C, Mullen GE, Pierce M, Martin LB, Rausch K, Dolo A, Diallo DA, Miller LH, Doumbo OK: A randomized and controlled Phase 1 study of the safety and immunogenicity of the AMA1-C1/Alhydrogel + CPG 7909 vaccine for Plasmodium falciparum malaria in semi-immune Malian adults. Vaccine 2009, 27:7292-7298.

117. Sagara I, Dicko A, Ellis RD, Fay MP, Diawara SI, Assadou MH, Sissoko MS, Kone M, Diallo Al, Saye R, Guindo MA, Kante O, Niambele MB, Miura K, Mullen GE, Pierce M, Martin LB, Dolo A, Diallo DA, Doumbo OK, Miller LH, Saul A: A randomized controlled phase 2 trial of the blood stage AMA1C1/Alhydrogel malaria vaccine in children in Mali. Vaccine 2009, 27:3090-3098.

118. Ouattara A, Mu J, Takala-Harrison S, Saye R, Sagara I, Dicko A, Niangaly A, Duan J, Ellis RD, Miller LH, Su XZ, Plowe CV, Doumbo OK: Lack of allelespecific efficacy of a bivalent AMA1 malaria vaccine. Malar J 2010, 9:175.

119. A Study of AdCh63 AMA1 Alone and With MVA AMA1. [http:// clinicaltrials.gov/ct2/show/NCT01095055]

120. Safety and Immunogenicity of EBA-175 RII-NG Malaria Vaccine Administered Intramuscularly. [http://clinicaltrials.gov/ct2/show/ NCT00347555].

121. El Sahly HM, Patel SM, Atmar RL, Lanford TA, Dube T, Thompson D, Lee Sim BK, Long C, Keitel WA: The safety and immunogenicity of recombinant EBA 175-RII NG malaria vaccine in healthy adults living in a non-endemic area. Clin Vaccine Immunol 17:1552-1559.

122. EBA-175 RII-NG malaria vaccine administered intramuscularly in semiimmune adults. [http://clinicaltrials.gov/ct2/show/NCT01026246].

123. Horii T, Shirai H, Jie L, Ishii KJ, Palacpac NQ, Tougan T, Hato M, Ohta N, Bobogare A, Arakaki N, Matsumoto Y, Namazue J, Ishikawa T, Ueda S, Takahashi M: Evidences of protection against blood-stage infection of Plasmodium falciparum by the novel protein vaccine SE36. Parasitol Int 2010, 59:380-386.

124. ISRCTN71619711 - BK-SE36 two-stage phase 1b vaccine trial for falciparum malaria. [http://www.controlled-trials.com/ISRCTN71619711].

125. Phase I study of the safety and immunogenicity of BSAM-2/Alhydrogel (Registered Trademark) + CPG 7909, an asexual blood stage vaccine for Plasmodium falciparum malaria in adults in the US and Mali. [http:// clinicaltrials.gov/ct2/show/NCT00889616].

126. A first-in-man clinical trial to evaluate the safety and immunogenicity of different doses of a malaria Vaccine (JAIVAC-1) in healthy Indian male subjects between 18 to 45 years of age. [http://www.ctri.nic.in/ Clinicaltrials/pmaindet2.php?trialid=1507].

127. Persson KE: Erythrocyte invasion and functionally inhibitory antibodies in Plasmodium falciparum malaria. Acta Trop 114:138-143.

128. Esen M, Kremsner PG, Schleucher R, Gassler M, Imoukhuede EB, Imbault N Leroy O, Jepsen S, Knudsen BW, Schumm M, Knobloch J, Theisen M, Mordmuller B: Safety and immunogenicity of GMZ2 - a MSP3-GLURP fusion protein malaria vaccine candidate. Vaccine 2009, 27:6862-6868.

129. Mordmuller B, Szywon K, Greutelaers B, Esen M, Mewono L, Treut C, Murbeth RE, Chilengi R, Noor R, Kilama WL, Imoukhuede EB, Imbault N, Leroy $\mathrm{O}$, Theisen M, Jepsen S, Milligan P, Fendel R, Kremsner PG, Issifou S: Safety and immunogenicity of the malaria vaccine candidate GMZ2 in malaria-exposed, adult individuals from Lambarene, Gabon. Vaccine 2010, 28:6698-6703.

130. Belard S, Issifou S, Hounkpatin AB, Schaumburg F, Ngoa UA, Esen M, Fendel R, de Salazar PM, Murbeth RE, Milligan P, Imbault N, Imoukhuede EB, Theisen M, Jepsen S, Noor RA, Okech B, Kremsner PG, Mordmuller B: A randomized controlled phase $\mathrm{lb}$ trial of the malaria vaccine candidate GMZ2 in African children. PLoS One 2011, 6:e22525.

131. Saul A, Lawrence G, Smillie A, Rzepczyk CM, Reed C, Taylor D, Anderson K, Stowers A, Kemp R, Allworth A, Anders RF, Brown GV, Pye D, Schoofs P, Irving DO, Dyer SL, Woodrow GC, Briggs WR, Reber R, Sturchler D: Human phase I vaccine trials of 3 recombinant asexual stage malaria antigens with Montanide ISA720 adjuvant. Vaccine 1999, 17:3145-3159.

132. Lawrence G, Cheng QQ, Reed C, Taylor D, Stowers A, Cloonan N, Rzepczyk C, Smillie A, Anderson K, Pombo D, Allworth A, Eisen D, Anders R, Saul A: Effect of vaccination with 3 recombinant asexual-stage malaria antigens on initial growth rates of Plasmodium falciparum in nonimmune volunteers. Vaccine 2000, 18:1925-1931.

133. Genton B, Al-Yaman F, Anders R, Saul A, Brown G, Pye D, Irving DO, Briggs WR, Mai A, Ginny M, Adiguma T, Rare L, Giddy A, Reber-Liske R, Stuerchler D, Alpers MP: Safety and immunogenicity of a threecomponent blood-stage malaria vaccine in adults living in an endemic area of Papua New Guinea. Vaccine 2000, 18:2504-2511.

134. Genton B, Al-Yaman F, Betuela I, Anders RF, Saul A, Baea K, Mellombo M, Taraika J, Brown GV, Pye D, Irving DO, Felger I, Beck HP, Smith TA, Alpers MP: Safety and immunogenicity of a three-component bloodstage malaria vaccine (MSP1, MSP2, RESA) against Plasmodium falciparum in Papua New Guinean children. Vaccine 2003, 22:30-41.

135. Genton B, Anders RF, Alpers MP, Reeder JC: The malaria vaccine development program in Papua New Guinea. Trends Parasitol 2003, 19:264-270.

136. Genton B, Betuela I, Felger I, Al-Yaman F, Anders RF, Saul A, Rare L, Baisor M, Lorry K, Brown GV, Pye D, Irving DO, Smith TA, Beck HP, Alpers MP: A recombinant blood-stage malaria vaccine reduces Plasmodium falciparum density and exerts selective pressure on parasite populations in a phase $1-2 b$ trial in Papua New Guinea. J Infect Dis 2002, 185:820-827.

137. Ockenhouse CF, Angov E, Kester KE, Diggs C, Soisson L, Cummings JF, Stewart AV, Palmer DR, Mahajan B, Krzych U, Tornieporth N, Delchambre M, Vanhandenhove M, Ofori-Anyinam O, Cohen J, Lyon JA, Heppner DG, Group MSPW: Phase I safety and immunogenicity trial of FMP1/AS02A, a Plasmodium falciparum MSP-1 asexual blood stage vaccine. Vaccine 2006, 24:3009-3017.

138. Thera MA, Doumbo OK, Coulibaly D, Diallo DA, Sagara I, Dicko A, Diemert DJ, Heppner DG, Stewart VA, Angov E, Soisson L, Leach A, Tucker K, Lyke KE, Plowe CV, Mali FMPWG: Safety and allele-specific immunogenicity of a malaria vaccine in Malian adults: results of a phase I randomized trial. PLoS Clin Trials 2006, 1:e34.

139. Stoute JA, Gombe J, Withers MR, Siangla J, McKinney D, Onyango M, Cummings JF, Milman J, Tucker K, Soisson L, Stewart VA, Lyon JA, Angov E, Leach A, Cohen J, Kester KE, Ockenhouse CF, Holland CA, Diggs CL, Wittes J, Heppner DG Jr: Phase 1 randomized double-blind safety and immunogenicity trial of Plasmodium falciparum malaria merozoite surface protein FMP1 vaccine, adjuvanted with AS02A, in adults in western Kenya. Vaccine 2007, 25:176-184.

140. Withers MR, McKinney D, Ogutu BR, Waitumbi JN, Milman JB, Apollo OJ, Allen OG, Tucker K, Soisson LA, Diggs C, Leach A, Wittes J, Dubovsky F, Stewart VA, Remich SA, Cohen J, Ballou WR, Holland CA, Lyon JA, Angov E, Stoute JA, Martin SK, Heppner DG, Group MSPMVW: Safety and reactogenicity of an MSP-1 malaria vaccine candidate: a randomized 
phase Ib dose-escalation trial in Kenyan children. PLoS Clin Trials 2006, 1: e32.

141. Malkin E, Long CA, Stowers AW, Zou L, Singh S, MacDonald NJ, Narum DL, Miles AP, Orcutt AC, Muratova O, Moretz SE, Zhou H, Diouf A, Fay M, Tierney E, Leese P, Mahanty S, Miller LH, Saul A, Martin LB: Phase 1 study of two merozoite surface protein 1 (MSP1(42)) vaccines for Plasmodium falciparum malaria. PLoS Clin Trials 2007, 2:e12.

142. Ellis RD, Martin LB, Shaffer D, Long CA, Miura K, Fay MP, Narum DL, Zhu D, Mullen GE, Mahanty S, Miller LH, Durbin AP: Phase 1 trial of the Plasmodium falciparum blood stage vaccine MSP1(42)-C1/Alhydrogel with and without CPG 7909 in malaria naive adults. PloS One 2010, 5: e8787.

143. Crompton PD, Mircetic M, Weiss G, Baughman A, Huang CY, Topham DJ, Treanor JJ, Sanz I, Lee FE, Durbin AP, Miura K, Narum DL, Ellis RD, Malkin E, Mullen GE, Miller LH, Martin LB, Pierce SK: The TLR9 ligand CpG promotes the acquisition of Plasmodium falciparum-specific memory $B$ cells in malaria-naive individuals. J Immunol 2009, 182:3318-3326.

144. Miura K, Zhou H, Diouf A, Moretz SE, Fay MP, Miller LH, Martin LB, Pierce MA, Ellis RD, Mullen GE, Long CA: Anti-apical-membrane-antigen-1 antibody is more effective than anti-42-kilodalton-merozoite-surfaceprotein-1 antibody in inhibiting Plasmodium falciparum growth, as determined by the in vitro growth inhibition assay. Clin Vaccine Immunol 2009, 16:963-968.

145. Pierce MA, Ellis RD, Martin LB, Malkin E, Tierney E, Miura K, Fay MP, Marjason J, Elliott SL, Mullen GE, Rausch K, Zhu D, Long CA, Miller LH: Phase 1 safety and immunogenicity trial of the Plasmodium falciparum blood-stage malaria vaccine AMA1-C1/ISA 720 in Australian adults. Vaccine 2010, 28:2236-2242.

146. Roestenberg $M$, Remarque $E$, de Jonge $E$, Hermsen $R$, Blythman $H$, Leroy $O$, Imoukhuede E, Jepsen S, Ofori-Anyinam O, Faber B, Kocken CH, Arnold M, Walraven V, Teelen K, Roeffen W, de Mast Q, Ballou WR, Cohen J, Dubois MC, Ascarateil S, van der Ven A, Thomas A, Sauerwein R: Safety and immunogenicity of a recombinant Plasmodium falciparum AMA1 malaria vaccine adjuvanted with Alhydrogel, Montanide ISA 720 or AS02. PloS One 2008, 3:e3960.

147. Saul A, Lawrence G, Allworth A, Elliott S, Anderson K, Rzepczyk C, Martin LB, Taylor D, Eisen DP, Irving DO, Pye D, Crewther PE, Hodder AN, Murphy VJ, Anders RF: A human phase 1 vaccine clinical trial of the Plasmodium falciparum malaria vaccine candidate apical membrane antigen 1 in Montanide ISA720 adjuvant. Vaccine 2005, 23:3076-3083.

148. Hu J, Chen Z, Gu J, Wan M, Shen Q, Kieny MP, He J, Li Z, Zhang Q, Reed ZH, Zhu Y, Li W, Cao Y, Qu L, Cao Z, Wang Q, Liu H, Pan X, Huang X, Zhang D, Xue $X$, Pan W: Safety and immunogenicity of a malaria vaccine, Plasmodium falciparum AMA-1/MSP-1 chimeric protein formulated in montanide ISA 720 in healthy adults. PLoS One 2008, 3:e1952.

149. Malkin E, Hu J, Li Z, Chen Z, Bi X, Reed Z, Dubovsky F, Liu J, Wang Q, Pan X, Chen T, Giersing B, Xu Y, Kang X, Gu J, Shen Q, Tucker K, Tierney E, Pan W, Long C, Cao Z: A phase 1 trial of PfCP2.9: an AMA1/MSP1 chimeric recombinant protein vaccine for Plasmodium falciparum malaria. Vaccine 2008, 26:6864-6873.

150. Hermsen CC, Verhage DF, Telgt DS, Teelen K, Bousema JT, Roestenberg M, Bolad A, Berzins K, Corradin G, Leroy O, Theisen M, Sauerwein RW: Glutamate-rich protein (GLURP) induces antibodies that inhibit in vitro growth of Plasmodium falciparum in a phase 1 malaria vaccine trial. Vaccine 2007, 25:2930-2940.

151. Clinical trial for malaria vaccines to test for safety, immune response and protection against malaria. [http://clinicaltrials.gov/ct2/show/ NCT00870987].

152. Sedegah M, Tamminga C, McGrath S, House B, Ganeshan H, Lejano J, Abot E, Banania GJ, Sayo R, Farooq F, Belmonte M, Manohar N, Richie NO, Wood C, Long CA, Regis D, Williams FT, Shi M, Chuang I, Spring M, Epstein JE, Mendoza-Silveiras J, Limbach K, Patterson NB, Bruder JT, Doolan DL, King CR, Soisson L, Diggs C, Carucci D, Dutta S, Hollingdale MR, Ockenhouse CF, Richie TL: Adenovirus 5-vectored $P$. falciparum vaccine expressing CSP and AMA1. Part A: Safety and immunogenicity in seronegative adults. PLOS One 2011, 6:e24586.

153. Tamminga C, Sedegah M, Regis D, Chuang I, Epstein JE, Spring M, Mendoza-Silveiras J, McGrath S, Maiolatesi S, Reyes S, Steinbeiss V, Fedders C, Smith K, House B, Ganeshan H, Lejano J, Abot E, Banania GJ, Sayo R, Farooq F, Belmonte M, Murphy J, Komisar J, Williams J, Shi M, Brambilla D, Manohar N, Richie NO, Wood C, Limbach K, Patterson NB,
Bruder JT, Doolan DL, King CR, Diggs C, Soisson L, Carucci D, Levine G, Dutta S, Hollingdale MR, Ockenhouse CF, Richie TL: Adenovirus-5-vectored P. falciparum vaccine expressing CSP and AMA1. Part B: Safety, immunogenicity and protective efficacy of the CSP component. PLOS One 2011, 6:e25868.

154. Genton B, Pluschke G, Degen L, Kammer AR, Westerfeld N, Okitsu SL, Schroller S, Vounatsou P, Mueller MM, Tanner M, Zurbriggen R: A randomized placebo-controlled phase la malaria vaccine trial of two virosome-formulated synthetic peptides in healthy adult volunteers. PloS One 2007, 2:e1018.

155. Okitsu SL, Silvie O, Westerfeld N, Curcic M, Kammer AR, Mueller MS, Sauerwein RW, Robinson JA, Genton B, Mazier D, Zurbriggen R, Pluschke G: A virosomal malaria peptide vaccine elicits a long-lasting sporozoiteinhibitory antibody response in a phase 1a clinical trial. PLoS One 2007, 2:e1278.

156. Thompson FM, Porter DW, Okitsu SL, Westerfeld N, Vogel D, Todryk S, Poulton I, Correa S, Hutchings C, Berthoud T, Dunachie S, Andrews L, Williams $J$, Sinden R, Gilbert SC, Pluschke G, Zurbriggen R, Hill AV: Evidence of blood stage efficacy with a virosomal malaria vaccine in a phase Ila clinical trial. PLoS One 2008, 3:e1493.

157. Cech PG, Aebi T, Abdallah MS, Mpina M, Machunda EB, Westerfeld N, Stoffel SA, Zurbriggen R, Pluschke G, Tanner M, Daubenberger C, Genton B, Abdulla S: Virosome-formulated Plasmodium falciparum AMA-1 \& CSP derived peptides as malaria vaccine: randomized Phase $1 \mathrm{~b}$ trial in semiimmune adults \& children. PLoS One 2011, 6:e22273.

158. Kashala O, Amador R, Valero MV, Moreno A, Barbosa A, Nickel B, Daubenberger CA, Guzman F, Pluschke G, Patarroyo ME: Safety, tolerability and immunogenicity of new formulations of the Plasmodium falciparum malaria peptide vaccine SPf66 combined with the immunological adjuvant QS-21. Vaccine 2002, 20:2263-2277.

159. Graves P, Gelband H: Vaccines for preventing malaria (SPf66). Cochrane Database Syst Rev 2006, CD005966.

160. Valero MV, Amador LR, Galindo C, Figueroa J, Bello MS, Murillo LA, Mora AL, Patarroyo G, Rocha CL, Rojas M: Vaccination with SPf66, a chemically synthesised vaccine, against Plasmodium falciparum malaria in Colombia. Lancet 1993, 341:705-710.

161. Alonso PL, Smith T, Schellenberg JR, Masanja H, Mwankusye S, Urassa H, Bastos de Azevedo I, Chongela J, Kobero S, Menendez C, Thomas MC, Lopez MC, Armstrong Schellenberg JRM, Hayes R, Smith T, Weiss N, Tanner M: Randomised trial of efficacy of SPf66 vaccine against Plasmodium falciparum malaria in children in southern Tanzania. Lancet 1994, 344:1175-1181.

162. Alonso PL, Tanner M, Smith T, Hayes RJ, Schellenberg JA, Lopez MC, Bastos de Azevedo I, Menendez C, Lyimo E, Weiss N: A trial of the synthetic malaria vaccine SPf66 in Tanzania: rationale and design. Vaccine 1994, 12:181-186.

163. D'Alessandro U, Leach A, Drakeley CJ, Bennett S, Olaleye BO, Fegan GW, Jawara M, Langerock P, George MO, Targett GA: Efficacy trial of malaria vaccine SPf66 in Gambian infants. Lancet 1995, 346:462-467.

164. Teuscher T, Schellenberg JR, Bastos de Azevedo I, Hurt N, Smith T, Hayes R, Masanja H, Silva Y, Lopez MC, Kitua A: SPf66, a chemically synthesized subunit malaria vaccine, is safe and immunogenic in Tanzanians exposed to intense malaria transmission. Vaccine 1994, 12:328-336.

165. Nosten F, Luxemburger C, Kyle DE, Ballou WR, Wittes J, Wah E, Chongsuphajaisiddhi T, Gordon DM, White NJ, Sadoff JC, Heppner DG: Randomised double-blind placebo-controlled trial of SPf66 malaria vaccine in children in northwestern Thailand. Shoklo SPf66 Malaria Vaccine Trial Group. Lancet 1996, 348:701-707.

166. Bojang KA, Obaro SK, Leach A, D'Alessandro U, Bennett S, Metzger W, Ballou WR, Targett GA, Greenwood BM: Follow-up of Gambian children recruited to a pilot safety and immunogenicity study of the malaria vaccine SPf66. Parasite Immunol 1997, 19:579-581.

167. Bojang KA, Obaro SK, D'Alessandro U, Bennett S, Langerock P, Targett GA, Greenwood BM: An efficacy trial of the malaria vaccine SPf66 in Gambian infants-second year of follow-up. Vaccine 1998, 16:62-67.

168. Acosta CJ, Galindo CM, Schellenberg D, Aponte JJ, Kahigwa E, Urassa H, Schellenberg JR, Masanja H, Hayes R, Kitua AY, Lwilla F, Mshinda H, Menendez C, Tanner M, Alonso PL: Evaluation of the SPf66 vaccine for malaria control when delivered through the EPI scheme in Tanzania. Trop Med Int Health 1999, 4:368-376. 
169. Metzger WG, Haywood M, D'Alessandro U, Drakeley CJ, Weiss H, Bojang K, Targett GA, Greenwood BM: Serological responses of Gambian children to immunization with the malaria vaccine SPf66. Parasite Immunol 1999, 21:335-340,

170. Ballou WR, Arevalo-Herrera M, Carucci D, Richie TL, Corradin G, Diggs C, Druilhe P, Giersing BK, Saul A, Heppner DG, Kester KE, Lanar DE, Lyon J, Hill AV, Pan W, Cohen JD: Update on the clinical development of candidate malaria vaccines. Am J Trop Med Hyg 2004, 71:239-247.

171. Malkin EM, Durbin AP, Diemert DJ, Sattabongkot J, Wu Y, Miura K, Long CA, Lambert L, Miles AP, Wang J, Stowers A, Miller LH, Saul A: Phase 1 vaccine trial of Pvs25H: a transmission blocking vaccine for Plasmodium vivax malaria. Vaccine 2005, 23:3131-3138.

172. Wu Y, Ellis RD, Shaffer D, Fontes E, Malkin EM, Mahanty S, Fay MP, Narum D, Rausch K, Miles AP, Aebig J, Orcutt A, Muratova O, Song G, Lambert L, Zhu D, Miura K, Long C, Saul A, Miller LH, Durbin AP: Phase 1 trial of malaria transmission blocking vaccine candidates Pfs 25 and Pvs 25 formulated with montanide ISA 51. PLoS One 2008, 3:e2636.

173. Miura K, Keister DB, Muratova OV, Sattabongkot J, Long CA, Saul A: Transmission-blocking activity induced by malaria vaccine candidates Pfs25/Pvs25 is a direct and predictable function of antibody titer. Malar J 2007, 6:107.

174. Qian F, Rausch KM, Muratova O, Zhou H, Song G, Diouf A, Lambert L, Narum DL, Wu Y, Saul A, Miller LH, Long CA, Mullen GE: Addition of CpG ODN to recombinant Pseudomonas aeruginosa ExoProtein A conjugates of AMA1 and Pfs 25 greatly increases the number of responders. Vaccine 2008, 26:2521-2527.

175. Qian F, Wu Y, Muratova O, Zhou H, Dobrescu G, Duggan P, Lynn L, Song G, Zhang Y, Reiter K, MacDonald N, Narum DL, Long CA, Miller LH, Saul A, Mullen GE: Conjugating recombinant proteins to Pseudomonas aeruginosa ExoProtein A: a strategy for enhancing immunogenicity of malaria vaccine candidates. Vaccine 2007, 25:3923-3933.

176. Initial Study of Malaria Vaccine Pfs25-EPA/Alhydrogel. [http://www. clinicaltrials.gov/ct2/show/NCT01434381].

177. Carlton JM, Sina BJ, Adams JH: Why is Plasmodium vivax a neglected tropical disease? PLoS Negl Trop Dis 2011, 5:e1160.

178. Moorthy V, Reed Z, Smith PG: Measurement of malaria vaccine efficacy in phase III trials: report of a WHO consultation. Vaccine 2007, 25:5115-5123.

179. Moorthy VS, Reed Z, Smith PG: MALVAC 2008: Measures of efficacy of malaria vaccines in phase $2 \mathrm{~b}$ and phase 3 trials-scientific, regulatory and public health perspectives. Vaccine 2009, 27:624-628.

180. Menendez C, Moorthy VS, Reed Z, Bardaji A, Alonso P, Brown GV: Development of vaccines to prevent malaria in pregnant women: WHO MALVAC meeting report. Expert Rev Vaccines 2011, 10:1271-1280.

doi:10.1186/1475-2875-11-11

Cite this article as: Schwartz et al:: A review of malaria vaccine clinical projects based on the WHO rainbow table. Malaria Journal 2012 11:11.

\section{Submit your next manuscript to BioMed Central and take full advantage of:}

- Convenient online submission

- Thorough peer review

- No space constraints or color figure charges

- Immediate publication on acceptance

- Inclusion in PubMed, CAS, Scopus and Google Scholar

- Research which is freely available for redistribution 